University of Rhode Island

DigitalCommons@URI

Open Access Master's Theses

1998

\title{
LAND USE REGULATION, TAKINGS LEGISLATION, AND THE WISE USE MOVEMENT IN SIX STATES
}

Ronald M. Wolanski

University of Rhode Island

Follow this and additional works at: https://digitalcommons.uri.edu/theses

\section{Recommended Citation}

Wolanski, Ronald M., "LAND USE REGULATION, TAKINGS LEGISLATION, AND THE WISE USE MOVEMENT IN SIX STATES" (1998). Open Access Master's Theses. Paper 576.

https://digitalcommons.uri.edu/theses/576

This Thesis is brought to you for free and open access by DigitalCommons@URI. It has been accepted for inclusion in Open Access Master's Theses by an authorized administrator of DigitalCommons@URI. For more information, please contact digitalcommons-group@uri.edu. 
LAND USE REgUlation, TAKINGS LEgISLATION, And The Wise Use Movement in Six States

BY

RONALD M. WOLANSKI

A Research Project Submitted in Partial Fulfillment OF THE REQUIREMENTS FOR THE DEGREE OF

MASTER OF COMMUNITY PlanNing

UNIVERSITY OF RHODE ISLAND

KINGSTON, RHODE ISLAND

1998 
MASTER OF COMMUNITy PLANNING

RESEARCH PROJECT

$\mathrm{OF}$

RONALD M. WOLANSKI

Approved:

Acknowledged:

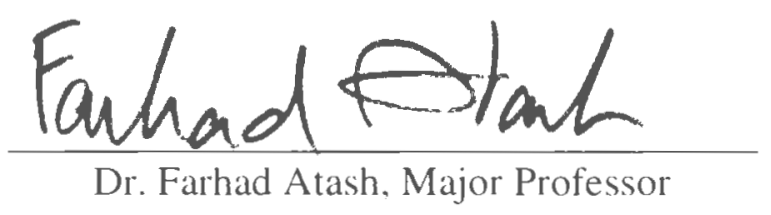

Found Stan

Dr. Farhad Atash, Director 


\section{ACKNOWLEDGMENTS}

This Masters Research Project is the culmination of many months of study and effort expended in the Graduate Curriculum in Community Planning and Area Development at the University of Rhode Island (CPAD). Through this time I have been the beneficiary of a great amount of support from my family, friends, and professors. It was not always easy, and I did not always express my appreciation to those who helped me. Now, as I am on the verge of being admitted to the degree of Master of Community Planning. I must recognize all who have contributed to this achievement.

I must first thank my Mom. Without the unending loving support and encouragement of my mother over the past few years, this achievement would not have been possible. I also thank my father, who always strove for excellence in all that he did. It is his example that I have always tried to emulate. Much thanks also to my sister for her support and encouragement throughout the years.

Through my time at CPAD I made many good friends. I will always remember the good times that we had together, and the help that they offered when called upon. Thank you to all my friends.

Thank you to the faculty and staff at CPAD. Due to their dedication. CPAD is a small program with a big impact on the planning profession. Special thanks to my Major Professor, Rolf Pendall. We both arrived at CPAD in the Fall of 1995. and became friends during our time together. Thanks go to Rolf for his enthusiasm, and for providing much needed, and much appreciated motivation.

I must recognize and thank the Rhode Island Agricultural Experiment Station for funding this research. This research project would not have been possible without the help of several individuals. Thank you to Dr. Rolf Pendall, for allowing me to be a part of his research. and for his assistance in my research. Many thanks also to Dr. Farhad Atash and Mr. Raymond Goff for their input into the completion of this project. Finally. thanks to all those who assisted in this effort by providing information, insight, and support. 


\begin{abstract}
INTRODUCTION

This project is the culmination of several months of research and data analysis on the Wise Use movement and takings legislation in six states (Kansas, Maine. Mississippi. Montana. Oregon, and Rhode Island). The aim of the research was to determine the relationship, if any. between the strength of environmental and land use regulation in the states and the prevalence of takings legislation. With a better understanding of the relationship of these factors, legislators, regulators, and planners will be better able address the concerns of constituents. My hypothesis was that the prevalence and strength of takings or property rights legislation is related to the strength of land-use and environmental regulation in the states.
\end{abstract}

\title{
BACKGROUND
}

The Wise Use movement bills itself as a grass-roots organization of property owners that wishes to regain the property rights that have been "taken" by federal, state and local governments through various environmental and land use regulations, and to influence federal policy relating to the use of public lands. The various adherents to the Wise Use movement are attempting to eliminate these regulations and are working to implement 
"takings" legislation in many states. Private property rights and takings legislation are just part of the agenda of Wise Use. The roots of the Wise Use movement are in the attempt to influence federal policy regarding the use of public lands by the extractive industries, including grazing rights and timber harvesting. The focus of this research is on takings legislation.

Takings legislation can be categorized by levels of strength. The strength ranges from measures that would require compensation by the government for regulation that is found to cause diminution of private property values, to others that simply require that new regulations be examined to determine the potential for conflict with Constitutional takings provisions.

Having an understanding of the current status of takings law is of extreme importance to planners. Over the past several decades there has been a narrowing of the limits to which regulation will be allowed to go. And with the current push of the Wise Use movement and takings bills in almost every state, planners should expect that there will be further change. This change will define what planners role's will be, and may require adaptation in planning practice.

\section{METHODOLOGY}

The project began with limited background research resulting in the formulation of my hypotheses. (discussed in Chapter 1) and the presentation of a research proposal. The research performed and this project was based on that proposal.

In conducting the research for this project I used a variety of sources of information and various methods of analysis. Data collection methods included research of state 
statutes, collection of takings bill text and outcomes, interviews, and other research.

Analysis included categorizing states and takings bills, and performing statistical analysis on the data collected. This combination of research and analysis has produced a complete, well rounded, and significant piece of research which sheds light on the Wise Use movement and takings legislation nationally and in Rhode Island.

\section{EXAMINATION OF THE STATES}

I examined the regulatory regimes and takings legislation regimes in six states: Kansas, Maine, Mississippi, Montana, Oregon, and Rhode Island. An inventory and classification of the planning and environmental regulatory regime in each state, and the rank of states according to this regime is provided. Also, an inventory of the takings legislation that has been introduced in each of the six states, including a typology of the types of legislation and the status of each bill is provided. Bills from each state are discussed in more depth to provide examples of the various types of legislation that have been introduced. Analysis of state regulatory regimes and the number and type of takings bills introduced in each state are provided to determine if there is a correlation between these factors.

The research found that there are some important correlations between the regulatory regimes and the legislative regimes in the states. Beginning with a detailed examination of the regulatory regimes of the states, and then the examination of the takings legislation, I concluded that the regulatory regime of the state does have an impact on the type and frequency of takings legislation that is introduced. Consistent with the hypothesis, the research determined that states with high levels of regulation also saw high numbers of 
takings bills introduced when compared to states with weak regulation. The research failed to prove, however, that states with weak regulation are more likely to enact strong takings legislation. The analysis also failed to show a relationship between the number of bills enacted and the regulatory regime of the state. The analysis did not show a strong statistical relationship between the regulatory regime and the strength of bills introduced, as was expected. However. creating a legislative regime by combining the strength of bills and number of bills for each state resulted in a finding of a strong positive correlation between the regulatory regime and this legislative regime. Those states with strong regulatory regimes also had strong legislative regimes.

\section{RHODE ISLAND: A CASE STUDY}

Even though Rhode Island is a small state, it has shown leadership in terms of planning and environmental regulation. And even though Rhode Island is intensely developed (having the second highest population density of all fifty states), there are some opponents to the State's efforts at regulation of development and protection of what remains of the natural environment.

The State of Rhode Island is a microcosm of the property rights debate. Many of the issues being debated in other states and at the national level have been addressed by the players in the state. Rhode Island, however, has not experienced the intensity of the property rights and Wise Uses movements that other parts of the country have seen. The most active area of contention in recent times has been dealing with environmental regulation. and the powers of the Rhode Island Department of Environmental Management (RIDEM). It may be that once the concerned public recognizes that change 
in the regulatory approach of RIDEM is moving forward, calls for takings legislation will diminish. My research has not identified any significant opposition to existing planning and land use regulations in the state. In fact, it appears that there may be some momentum in the direction of increased efforts to limit development sprawl into rural communities.

\section{CONCLUSIONS}

Previous research on Wise Use, together with my research, identified the foundation of the property rights debate to be constitutional takings law. In general, environmental and land use regulation has been held as a constitutionally acceptable exercise of the government's police powers to protect the health, safety, and welfare of the populace. Wise Use Groups and other individuals involved in the debate contend that regulation of land use infringes on constitutional protections. Gaining an understanding of the arguments against such regulation is vital to being able to combat the attempts to dismantle planning and environmental protection.

The states with the strongest regulation saw the highest number of bills introduced. This indicates that the existence of regulations that are thought to impact property rights has the effect of inducing property rights activists and Wise Use organizations to influence legislators to introduce takings legislation.

The analyses reveal that even if high numbers of bills and strong bills are introduced in the legislature of these states, "cooler heads" have generally prevailed. When bills have been enacted. they have usually been the type that establish study commissions or that require state agencies to consider the takings implications of regulations. These types 
of bills do not directly impact the power to regulate land use, and therefore are not a direct threat to necessary and prudent planning and environmental regulation.

The research has led to the conclusion that there have been many takings bills introduced in Rhode Island precisely because of the progressive regulatory regime. The core issue in Rhode Island is wetland and other RIDEM regulations. Based on this information, my conclusion and prediction is that once the issue of regulatory misconduct by RIDEM is fully addressed, and the horror stories go away, RI Wise Use will lose much of its already limited support. Planners must remain cognizant of the arguments on both sides of the issue in order to respond to future Wise Use initiatives. They must also recognize the implications of regulation, and its impact on property rights. In some cases, Wise Use groups have identified legitimate excesses of regulatory power. Planners and regulators should not disregard such claims, but should investigate and correct these problems.

It is hoped that this work will inspire further research into the Wise Use movement. This research was fairly limited in scope. It provides cursory examination of only six states, with in-depth study of only one state. Future research should expand on this by conducting in-depth research of more states. 


\section{Table of Contents}

ACKNOWLEDGMENTS i

$\begin{array}{ll}\text { ABSTRACT } & \text { ii }\end{array}$

LIST OF TABLES $\quad \mathbf{x}$

CHAPTER 1: INTRODUCTION 1

THE WISE USE MOVEMENT \& TAKINGS LEGISLATION 1

EXAMINATION OF THE STATES 2

RHODE ISLAND: A CASE STUDY 3

JUSTIFICATION 3

QUESTIONS 4

HYPOTHESES

Chapter 2: BaCkgRound $\quad 7$

INTRODUCTION

THE WISE USE MOVEMENT

Sources of Support $\quad 8$

Types of Groups $\quad 9$

Main Strategies $\quad 12$

PREVIOUS RESEARCH 16

CONSTUTIONAL TAKINGS 19

The Legal Context 19

CONCLUSSION

$\begin{array}{ll}\text { The Planning Context } & 23\end{array}$

ChaPter 3: Methodology $\quad 24$

INTRODUCTION 24

BACKGROUND $\quad 24$

ANALYSIS OF STATE STATUTES $\quad 25$

ANALYSIS OF STATE TAKINGS LEGISLATION 26

CORRELATIONS BETWEEN REGULATORY

AND LEGISLATIVE REGIMES $\quad 28$

A CASE STUDY OF RHODE ISLAND $\quad 30$

CONCLUSION

Chapter 4: Examination of the States $\quad \mathbf{3 3}$

INTRODUCTION

ANALYSIS OF STATE STATUTES 33

Typology of Statutes $\quad 33$

$\begin{array}{ll}\text { State Regulatory Regimes } & 37\end{array}$

ANALYSIS OF STATE TAKINGS LEGISLATION 38 
Chapter 4: Examination of The States (CONT.)

Typologies of Legislation 38

Bills in the Six States 39

Summaries of legislation $\quad 39$

Analysis of legislation $\quad 48$

State Legislative Regimes $\quad 50$

CORRELATIONS BETWEEN REGULATORY

AND LEGISLATIVE REGIMES

Regulatory Regime and Number of Bills Introduced 52

Regulatory Regime and Strength of Bills

Regulatory Regime and Legislative Regime 53

CONCLUSIONS

ChaPTer 5: Rhode Island: A Case Study 56

INTRODUCTION $\quad 56$

REGULATORY REGIME

Planning Regulation $\quad 57$

Environmental Regulation $\quad 58$

TAKINGS LEGISLATION 60

Perspective of a Legislative Analyst 61

The Rhode Island Constitution 63

RHODE ISLAND WISE USE

Organization $\quad 68$

A RI Wise Use Meeting 69

THE LIGHTNING ROD: RI DEM 74

CONCLUSION 78

Chapter 6: Conclusions $\quad 79$

WISE USE $\quad 79$

TAKINGS LEGISLATION AND THE STATES

IMPLICATIONS FOR RHODE ISLAND 83

LIMITATIONS/FUTURE RESEARCH 84

$\begin{array}{lr}\text { REFERENCES } & \mathbf{8 6}\end{array}$

Appendix A: Statistical Calculations

APPENDix B：AdDitional, READINGS 


\section{LIST OF TABLES}

Table 1-1 Expected Results $\quad 6$

Table 4-1 State Planning, Zoning, and Environmental Regulations 34

$\begin{array}{ll}\text { Table 4-2 State Takings Legislation } & \mathbf{4 0}\end{array}$

Table 4-3 Legislative Summary 49

Table 4-4 Legislative Analysis: Outcome vs. Type 49

Table 4-5 Legislative Analysis: Outcome vs. Type 50

Table 4-6 State Legislative Summary

Table 4-7 Legislative Analysis: Outcome vs. Regulatory Regime 52

Table 4-8 Legislative Analysis: Bill Type vs. Regulatory Regime 54 


\section{CHAPTER 1}

\section{INTRODUCTION}

This research project is the culmination of several months of research and data analysis on the Wise Use movement and takings legislation in six states (Kansas, Maine, Mississippi, Montana, Oregon, and Rhode Island). The aim of the research was to determine the relationship. if any, between the strength of environmental and land use regulation in the states and the prevalence of takings legislation. The issues to be addressed in this work are introduced below.

\section{THE WISE USE MOVEMENT \& TAKINGS LEGISLATION}

Chapter 2. Background, provides an in-depth discussion of the Wise Use Movement and takings legislation. The "Wise Use" movement bills itself as a grass-roots organization of property owners that wishes to regain the property rights that have been "taken" by federal. state and local governments through various environmental and land use regulations, and to influence federal policy on the use of public lands (Echeverria \& Eby 1995). The various adherents to the Wise Use movement are attempting to eliminate these regulations and are working to implement "takings" legislation in many states. Private property rights and takings legislation are just part of the agenda of Wise Use. The roots of the Wise Use movement are in the attempt to influence federal policy regarding 
the use of public lands by the extractive industries, including grazing rights and timber harvesting (Echeverria \& Eby 1995). The focus of this research is on takings legislation.

Takings legislation can be categorized by levels of strength. The strength ranges from measures that would require compensation by the government for regulation that is found to cause diminution of private property values, to others that simply require that new regulations be examined to determine the potential for conflict with Constitutional takings provisions (Emerson 1996. Thomas 1996).

The Fifth Amendment to the United States Constitution contains the clause, “. . nor shall private property be taken for public use, without just compensation." This language has also been incorporated into many state constitutions. It is this language that private property rights advocates employ as the basis for their initiatives. They contend that landuse and environmental regulations have taken property values from property owners through limits on potential use. Many Wise Use initiatives seek "just compensation" for this loss of property value (Center for the Defense of Free Enterprise 1997).

\section{EXAMINATION OF THE STATES}

Chapter 4 presents the examination of the six states. It begins with a discussion of the regulatory regime in each state based on environmental and planning statutes. The states are categorized based on the their regulatory regime. An analyses of takings legislation introduced in the six states is then presented. Finally, Chapter 4 presents the analyses to determine the correlation between these variables. The methodology behind these analyses is presented in Chapter 3, which also discusses the process of data collection. 


\section{RHODE ISLAND: A CASE STUDY}

Chapter 5 presents a comprehensive look at the state of environmental and planning regulation in Rhode Island. There is an extensive discussion of the Wise Use movement and the prevalence of takings legislation in the state. This examination provides an opportunity to look beyond the numbers to reveal the politics and personalities involved in the property rights debate in one state.

\section{JUSTIFICATION}

This research is important to state legislators who introduce and vote on land-use and environmental measures, and legislation that would be classified as takings. It is also important to state and local regulatory officials who are charged with implementing such measures. Legislators should understand that the input they receive from interest groups. such as the Wise Use movement and environmental groups, and the general public may be influenced by the current regime of planning and environmental regulation. With a better understanding of the relationship of these factors, legislators, regulators, and planners will be better able address the concerns of constituents. Understanding why there is a backlash against government regulation will help them to implement regulations that will provide for land use control and environmental regulation at a level that will be acceptable to the general population. The acceptability of regulation will affect the prevalence and power of the Wise Use movement in the states. Without a strong sentiment of concern over the imposition of reasonable regulation. the interest of the average citizen is not likely to be raised. Without this ground-swell of popular support, 
grass-roots private property initiatives are less likely to become a factor in political decision making. This is discussed in Chapter 6, Conclusions.

The Wise Use movement can be viewed at all levels of government: national, state. and local. This research, funded by the Rhode Island Agricultural Experiment Station, is significant, in that it examines each of these levels. By examining states in various regions of the country, a pattern begins to emerges that helps provide an understanding of the influence of Wise Use at the national level, and by region. This helps to show the implications for planning and regulatory efforts in each region of the country.

Research on six different states provides case studies of Wise Use efforts at the state level. State regulatory officials and planners in Rhode Island, and elsewhere, would benefit from an understanding of property rights issues and the arguments of Wise Use groups. Similarly, local officials, including planning and zoning board members should have a good understanding of these issues. Such understanding by officials at the state and local level might result in less confrontation over the implementation of land use and environmental regulation. The results of this research would be a useful tool in educating these officials.

\section{QUESTIONS}

This research project attempts to answer the following three questions: (1) Does the regulatory regime of a state correspond to the strength and/or success. or introduction frequency of takings legislation? If there is some correspondence, what is the nature of the relationship? (2) Do states with a stronger regime of regulation experience a greater 
interest in takings legislation and attention from Wise Use groups? (3) What are the implications for regulation and planning in Rhode Island?

\section{HYPOTHESES}

The overall hypothesis of this research project was that the prevalence and strength of takings or property rights legislation is related to the strength of land-use and environmental regulation in the state. From this, several questions were explored through the research. Prior research indicates that states with the strongest environmental commitment and capacity for protection, generally had no property rights measures, or only weak measures enacted (Emerson 1996). Therefore, I expected to find that in the states with strong regulatory regimes, some strong measures would have been introduced in the legislatures. Also, I expected that there would generally be a higher total number of bills introduced in these states compared to weak regulatory states. These actions might be explained by the Wise Use movement and other forms of backlash against strong regulation in these states. Furthermore, this might result in the introduction of many takings bills in the legislature. However, because of the commitment to environmental protection and regulation only weak bills, if any, would be enacted.

Some of the strongest measures were enacted in states with weak environmental protection commitment and capacity (Emerson 1996). In these states I expected to find that while strong measures were enacted. this does not necessarily mean that there were a high number of bills introduced. I expected to find that strong takings statutes would have been enacted in these states and therefore there would be a limited total number of takings bills introduced. Also, a higher percentage of the bills introduced would be enacted. 
Because of the already weak commitment to environmental protection in these states there might be limited interest in further limiting regulation. Where legislation is introduced. it might be expected that stronger legislation would be enacted. I would expect less opposition to such legislation in these cases, again due to the states' lack of commitment to environmental protection. Table 1-1 summarizes the results that were expected based on these hypotheses.

Table 1-1 Expected Results

\begin{tabular}{|c|c|c|c|c|}
\hline \multirow[t]{2}{*}{ Regulatory Regime } & \multicolumn{2}{|c|}{ Bills Introduced } & \multicolumn{2}{|c|}{ Bills Enacted } \\
\hline & Number & Strength & \%. Enacted & Strength \\
\hline Weak Regulation & few & strong & high & strong \\
\hline Strong Regulation & many & weak \& strong & low & weak \\
\hline
\end{tabular}

The results of the analyses of the data that were collected over the course of the research are presented in Chapter 4 of this research project. 


\section{Chapter 2}

\section{BACKGROUND}

\section{INTRODUCTION}

This chapter gives the background information needed to frame the discussion of the research that follows later in the research project. First. is the discussion of the Wise Use movement in some depth. It is this movement that has increased the pressure on legislators to introduce and support takings legislation in the states. An understanding of the positions of Wise Use groups is essential in understanding the current increased legislative activity. Next is the discussion of some of the research done by others in the planning field on this topic. Finally is the discussion of the legal underpinnings of the current debate.

\section{THE WISE USE MOVEMENT}

The Wise Use movement bills itself as a grass-roots organization of property owners that wishes to regain the property rights that have been "taken" by federal, state and local governments through various environmental and land use regulations (Echeverria \& Eby 1995). The various adherents to the Wise Use movement are attempting to eliminate these regulations and are working to implement "takings" legislation in many states. Private property rights and takings legislation are just part of the agenda of Wise Use. The roots 
of the Wise Use movement are in the attempt to influence federal policy regarding the use of public lands by the extractive industries, including grazing rights and timber harvesting (Echeverria \& Eby 1995).

\section{Sources of Support}

There has been debate between members of the Wise Use movement and members of environmental groups over the validity of the "grass-roots" label. Some environmentalists claim that resource recovery industries, such as timber and mining. organize and fund the initiatives of Wise Use groups (Lewis 1995). Some claim that the movement's main source of support comes from 15 to 20 organizations whose members serve on each other's boards (Gallagher 1996). And though millions of dollars do come from the extractive industries to support these groups, training and other support is also provided, and is not accounted for in the contributions (Gallagher 1996). In fact, one Wise Use group, The Alliance for America, claimed to have a 1994 budget of under $\$ 60,000$ with grassroots members raising funds through bake sales and auctions: however, listed as participants in one of the group's events were the Arizona Cattleman's Association, the Northwest Mining Association, and the Southern Timber Purchasers Council (Gallagher 1996). David Helvarg has estimated that the Wise Use movement has fewer than 100,000 real activists, and some environmentalists say that the number may be only in the tens of thousands (Pertman 1994). These facts, however, do not disprove that there is some level of grass roots support in addition to any corporate support. Pendall et al. (1997) propose that there is a "property culture," particularly evident when comparing urban and rural areas, that explains support for takings legislation promoted by the Wise Use movement. Property culture refers to the various characteristics of a population that, when combined. 
help to explain attitudes toward an issue, such as takings legislation. The characteristics might include, but are not limited to political party affiliation, the region of the country, economic reliance on agriculture, race, and income level.

\section{Types of Groups}

As many as 250 groups fall under the umbrella of the Wise Use movement, including for example, the Center for the Defense of Free Enterprise, People for the West!, Multiple Use Land Alliance. and the National Wetlands Coalition (Watkins 1995). Probably the most active and prolific advocate for the Wise Use and private property rights cause is Ron Arnold and his organization, The Center for the Defense of Free Enterprise. Arnold takes exception with the argument that the Wise Use movement is not a grass-roots phenomenon. He claims that the movement includes 1,500 groups representing three million people nationwide (Gallagher 1996). The Center for the Defense of Free Enterprise (1997) proclaims its beliefs as:

1. Humans, like all organisms, must use natural resources to survive.

2. The earth and its life are tough and resilient, not fragile and delicate.

3. We only learn about the world trough trial and error.

4. Our limitless imaginations can break trough natural limits to make earthly goods and carrying capacity virtually infinite.

5. Man's reworking of the earth is revolutionary, problematic and ultimately benevolent.

Arnold and the Center's founder, Allen Gottlieb, appear to be the self-appointed leaders of the Wise Use movement. In fact, it was Arnold who adopted the term "wise use" as the name of the movement; borrowed from the first U.S. Forest Service head, Gifford Pinchot's definition of conservation: "the wise use of resources" (Lewis 1995). The Center for the Defense of Free Enterprise sponsored a conference in 1988 that 
brought together over 200 Wise Use organizations, and resulted in the movement's 25 -

point agenda (CLEAR 1996). The agenda included the following selected items:

- Develop the petroleum resources of the Arctic National Wildlife Refuge in Alaska:

- Advocate the passage of the Inholders Protection Act, giving broader property rights to landowners within or adjacent to federal lands;

- Support old growth logging as part of the "Global Warming Protection Act" (increasing young stands on National Forest lands);

- $\quad$ Open all public lands to mining and energy production;

- Create a national timber harvesting system to allow greater harvesting on public lands:

- $\quad$ Reorganize the National Parks Service to allow maxinum public entry and concessions in parks:

- Create National Rangeland Grazing System to open more federal lands for grazing:

- Open all wilderness areas to motorized wheelchair access;

- $\quad$ Require greater specificity in identifying the costs associated with actions by federal agencies, and;

- $\quad$ Amend and weaken the Endangered Species Act.

According to their Internet web site, the Center also supports several of its own projects, including: Free Enterprise Press, a publishing house devoted to works on liberty, property rights and free enterprise: Free Enterprise Legal Defense Fund, which assists individuals in actions against government regulation; American Press Syndicate, which distributes materials to print media; American Broadcasting Network, which distributes PSA's to the electronic media; Community Organizing, which trains local community activists; Organizational Networking, which puts various groups in contact with each other (Center for the Defense of Free Enterprise 1997).

Interestingly. Ron Arnold worked for environmental protection in the late 1960`s and early 70's (Ramos 1995). He was a member of the Sierra Club and worked for the Alpine Lakes Protection Society (ALPS), a group dedicated to the protection of alpine lakes in Washington state. Arnold eventually started his own media relations firm with clients in 
the timber and pesticide industries (Ramos 1995). He went on to write articles attacking the environmental movement. and advocating that industry use the tactics of environmental activists to defeat them. He promoted organized industry activism against environmental protection which has become the cornerstone of the Wise Use movement.

Citizens for a Sound Economy is another group which promotes the limitation of government regulation. On the issue of environmental regulation the group states that it "seeks to protect the American way of life without relying on absurd regulations and bureaucratic paperwork which cripple the economy."(CSE 1997)

Similar groups include the National Federal Lands Conference. based in Bountiful. Utah, an organization active in the county supremacy movement discussed below. However, they choose to use the laws on the books in order to work with the state and federal governments for the joint management of federal lands (Gallagher 1996). The Alliance for America. mentioned above, was founded in 1991 by David Howard and says its main priority is education: "showing Congress what these [environmental] laws do to people. We'd like to bring back some common sense" (Gallagher 1995, p. 9). Alliance for America also sponsors the annual "Fly-In for Freedom," which includes workshops and lobbying efforts.

It seems that the Wise Use movement has taken hold in a time when environmental regulations, which have been in place for more than twenty years, are becoming ever stricter. Particularly, the Endangered Species Act (ESA) (U.S.C. Title 16. Ch. 35. Section 1531) has become increasingly controversial over the past several years. Most notably, the fight over logging in old-growth forests in the Pacific-Northwest came to a head when the identification of the spotted owl as an endangered species stopped 
logging in some areas (Ramos 1995). The movement is also addressing issues in the states. An issue in many states. including Rhode Island, is wetland regulation. My research into state regulations to this point indicates that regulation to protect wetlands has become common in many states. Some property owners, whose ability to use or develop land has been impacted by these regulations, have claimed that they should be compensated for loss of property value.

\section{Main Strategies}

The Wise Use movement is active at many levels of government in the United States. State Legislation that would limit regulatory authority is one of the latest, and most successful tactics of the wise use movement. The movement has been successful in getting significant legislation passed in 18 states, with parallel legislative activity in the U.S. Congress and over 200 counties (Jacobs 1996). Many of the efforts in the individual states are being coordinated at the national level by groups such as the American Legislative Exchange Council and Defenders of Property Rights (Lavelle 1995). These efforts have found sympathetic ears among state legislators, usually Republican (Pendall et al. 1997).

\section{State Legislation}

States in the west have expressed frustration for their lack of control over federal land. Anger is directed at federal agencies (Bureau of Land Management and the U.S. Forest Service) that have control over grazing fees and logging restrictions. Many areas in western states rely almost entirely on industries that utilize federal land (Gallagher 1996). It was similar frustration over environmental regulations that sparked the "Sagebrush Rebellion" of the $1970^{\circ}$ s. Greater control over federal lands by states and private land 
owners was seen as a way to avoid the new wave of environmental regulation that impacted the use of federal lands (Lewis 1995).

The focus of this research project is on the actions that have been taken to attempt to implement new laws and policies in state government that would address the concerns of property owners adversely impacted by regulations. These are often referred to as takings bills. Such a bill may constitute a policy that requires regulators to perform a cost/benefit analysis prior to implementing new regulations. It may require payment for loss of property value. There may simply be a requirement to review the proposed regulation to determine its takings implications. It is an attempt to have an impact on the regulator's and politician`s decision making processes regarding enactment of environmental and land use laws and regulations. The outcomes have been mixed. Some states have enacted anti-takings legislation, but typically only weak legislation passes. However. some states have enacted stricter provisions (Emerson 1996, Thomas 1996). Previous research into the efforts of the wise use movement in the states is discussed in more depth in the next section of this chapter.

\section{County Supremacy}

One arm of the larger Wise Use movement is the county supremacy movement, which began in Catron County. New Mexico in 1992 (Jacobs 1996, Williams 1995, Gallagher 1996). Residents claimed that, as a result of efforts by the U.S. Forest Service to protect the Mexican Spotted Owl, the area's timber industry was brought to a standstill. The county adopted a plan that stated that federal agencies must consider county traditions and economic stability prior to action, and must mitigate any negative impacts. In 1993 the county also asked that management of federal lands be transfered to the county. 
Although this did not happen, a memorandum of understanding was signed by the county and federal officials in which the federal government recognized that the National Environmental Policy Act, and Forest Service and Bureau of Land Management statutes require federal plans to consider local plans (Gallagher 1996).

As many as 45 counties in six states have drafted ordinances similar to Catron County's in an effort to limit the power of the federal government (Williams 1995). Much of the activity has been in western states, including Montana, Idaho, Wyoming, New Mexico, Utah. Nebraska and California. One planning consultant estimates that a quarter of the counties in the west are involved (Williams 1995). In Nye County, Nevada (home of the "Sagebrush Rebellion") county supremacists and Wise Use advocates bulldozed open a U.S. Forest Service Road in 1994. This was intended to enforce a 1993 county resolution that was based on a 1979 statute that declared that the state owns federal lands. and that the county has the authority to manage them (Gallagher 1996). The Justice Department filed suit against the county, with the state submitting a brief admitting that it had no claim to the federal lands.

\section{National Efforts}

It should also be noted that the Wise Use movement has made efforts. and has had some successes in influencing policy at the national level. The private property rights movement is credited with influencing Ronald Reagan's 1988 Executive Order which essentially required a private property rights impact statement on all federal regulatory action (Jacobs 1996). Legislative proposals have been continually introduced in Congress in an attempt to codify that order (Jacobs 1996). The Wise Use movement has also been credited with helping to prevent the Environmental Protection Agency from attaining 
Cabinet Status (Pertman 1994).

The movement has also been involved in many controversies relating to the extractive industries. In addition to the fight over logging in old-growth forests in the Pacific Northwest the issue of national policy over grazing rights and fees on federal lands has been taken on by the movement (Riebsame \& Woodmansee 1995). The Clinton Administration had attempted to restructure the fee system for ranchers to graze cattle on federal lands. This was met with much resistance from ranchers, who have raised the issue of government interference with the use of property that they feel should be privately held (Jacobs 1996). They also helped to weaken legislation supported by Interior Secretary Bruce Babbitt to establish a national biological survey of native plants, animals. and ecosystems (Pertman 1994).

\section{Grass Roots}

There are also activities sponsored or organized by individual Wise Use groups. The "Fly-In for Freedom" is organized by the Alliance for America, and is a several day event including workshops and lobbying efforts. In the past, speakers have included House Speaker Newt Gingrich (CLEAR 1996). Four-hundred participants attended the 1995 FlyIn, which was held in Washington, D.C. (Gallagher 1996). Also, Brian Bishop of Rhode Island Wise Use has organized an effort to bring western Wise Use leaders to speak on eastern college campuses, and to appear on radio talk shows and in news papers (CLEAR 1996). 


\section{PREVIOUS RESEARCH}

The focus of the research in this paper is the actions that have been taken by the Wise Use movement to attempt to implement new laws and policies in state government that would address the concerns of property owners impacted by regulations: takings bills. It is an attempt to have an impact on the regulator's and politicians' decision making processes regarding enactment of environmental and land use laws and regulations. Following is an examination of the types of bills that have been considered or adopted in the states.

Takings bills have been considered in 49 states during the 1980's and 1990's (ARIN 1996, Emerson 1996). Over three-hundred bills have been introduced, with at least 52 measures being adopted in 26 states (Emerson 1996). These bills have been adopted in all regions of the country. with the great plains and western states being well represented (Emerson 1996. Thomas 1996). The states chosen for examination in this research project (Maine, Mississippi, Kansas, Montana, Oregon, and Rhode Island) represent several regions of the country and varying regimes of regulatory strength.

Takings bills can be evaluated by examining some of their major characteristics. Thomas (1996) looked at nine aspects of each of several bills in his typology, including: purpose, parties required to act, the standard for a taking, and whether compensation is provided for. An examination of these factors gives a good indication of the strength of a takings bill. Thomas (1996) identifies two levels of language for bills. The first level is defined as the statement of purpose. The second level of the bill is that which identifies a policy objective. For example, the Kansas legislation is intended to reduce the risk of 
undue burdens on property owners (Thomas 1996). Several bills examined by Thomas do not express the ultimate policy objective.

Takings bills can also be represented over a range of severity in terms of the action or policy which they impose. Emerson (1996) describes four categories of takings bills: preliminary measures, assessment provisions, entitlement bills, and conflict resolution measures. Preliminary measures can be further distinguished between symbolic declarations and legislative study commissions. Emerson explains that preliminary measures are often a first step in gaining support for further legislation. These measures can also be a way of diffusing conflict. Conflict resolution measures provide for some form of administrative process to resolve disputes, while not directly addressing the statutes or regulations. These measures might provide for administrative appeals or third party intervenors. Assessment measures generally require that the government review the takings implications of proposed rules and regulations in order to avoid litigation. These measures have also been used as a way to restrain the regulatory actions of government. Nationwide, this is the most common type of takings legislation (Emerson 1996). Finally. entitlement measures are those that are designed to strengthen private property rights. This is done in either of three ways: limiting public rights, protecting existing private rights, or creating new rights. Compensation bills, such as the Mississippi bill described in Chapter 4, fall into this category. Entitlement measures often require that takings assessments be conducted on portions of the larger piece of property, rather than than the entire parcel. This favors the land owner by increasing the percentage land value for the smaller piece of land that is affected by the regulation. 
Of fifty-nine bills examined by Emerson (1996), twenty-five were assessment. thirteen were preliminary, twelve were entitlement, and nine were conflict resolution. Similar to Thomas's typology, Emerson examines the characteristics of bills in each of the four categories.

Also, a model bill drafted for the American Legislative Exchange Council, an organization of conservative state legislators, and introduced in several states, would require compensation of a property owner who could show a $50 \%$ reduction in property value as a result of regulation (Lavelle 1995). Such bills are at the stricter end of the scale.

Takings bills of any type will have an impact on local planning and zoning practices. Bills that establish study committees to review the issue of takings could, at the very least, delay passage and implementation of any new or revised land use regulation pending the completion of the study. At the other end of the scale, compensation bills would likely result in the prohibition of any new regulation that would subject the state or local government to new financial responsibility. This might halt any new efforts toward growth control and better land use management techniques for fear of financial responsibility.

Research recently conducted indicates that while the Wise Use movement in the states may have a role in the introduction and success of takings legislation, other factors also play a role. The study proposed that there is a "property culture" that exists in this country. A major finding was that legislators in urban areas are more likely to oppose takings legislation, and those in rural areas are more likely to support such bills (Pendall et al. 1997). 
The research presented in this paper complements the previous work by taking another step toward an understanding of the factors that may impact the introduction and implementation of takings legislation in the states.

\section{CONSTUTIONAL TAKINGS}

The major underlying issue addressed in all takings bills is the extent of government regulation that constitutes an unconstitutional taking of private property. As mentioned above, there are varying levels of strength of takings. Some of the strongest bills are those that define a new standard for what constitutes a taking; that is, instead of relying on the current interpretation of the fifth and fourteenth amendments to the U.S. Constitution by the courts, such bills explicitly state the criteria for determining when a taking has taken place. As will be discussed in Chapter 4, bills in Mississippi and Oregon took this approach.

\section{The Legal Context}

The Fifth Amendment to the U.S. Constitution states that, “. . . nor shall private property be taken for public use, without just compensation." This language has also been incorporated into several state constitutions. This language and the "due process" clause of the Fourteenth Amendment are the basis on which all takings claims by property owners are raised. It is the ambiguity in the case law that takings bills attempt to address.

Local land use regulation is generally protected as a legitimate use of the police power, provided that it is intended to protect the health. safety. and general welfare of the community. As Justice Holmes stated in Pennsylyania Coal v. Mahon, 260 U.S. 393 (1922). regulations that go "too far" violate the Constitution and "will be recognized as a 
taking." While there has been debate through the years as to whether the word "taking" as used by Holmes should be taken literally, it is clear that regulation that goes too far violates the Constitution.

An important difference between a due process and a taking violation has to do with the remedy. In cases where it is found that a taking without compensation has occurred, the remedy is normally to require compensation for the loss of property value resulting from the regulation. However, as was seen in Maryland Nat'l Capital Park and Plamning Comm'n v. Chadwick, 405 A.2d 241 (1979), where a "taking"' was remedied by invalidation of the regulation, this is not always the case. A due process violation will normally result in invalidation of the regulation: there is no compensation. In French Investment Co. v. City of New York, 350 N.E.2d 381 (1976) the court distinguished between a compensable taking and a due process violation. When private property is appropriated for public use, compensation is required. Excessive regulation of use of private property results in invalidation of the ordinance: compensation is not a remedy. This case also describes a three part test to determine a due process violation: First, is there a legitimate government purpose for the regulation; Second, is the regulation a rational means to the end; Finally, do the public benefits out way the private burden. In Lucas v. South Carolina Coastal Council, 112 S. Ct. 2886 (1992) the U.S. Supreme Court found that a compensable taking occurs when the owner is deprived of all beneficial use of his property. Even temporary takings have been found to be compensable by the Court. In First Evangelical Lutheran Church v. County of Los Angeles. 482 U.S. 304 (1987) the Court stated that if a regulation temporarily deprives an owner the use of his land, the owner is entitled to compensation for the value lost during 
that period of time.

In cases where an argument of a violation of the due process or takings clauses was denied by the court, it was often because the court found that the regulation was within the police power of the municipality, and that there was no complete loss of the use or value of the property. Mugler 1. Kansas. 123 U.S. 623 (1887) is an interesting case because there was a total loss of the use of a brewery and its inventory, yet the court decided the case strictly on the due process question, finding that there was no physical invasion by the state. and therefore no compensation was required as in a takings case. This case would probably be decided differently under Lucas, where it was found that a regulation that results in a total loss of value is a taking. Also, even though there was no invasion by the state in Lacas, the state court had found. following the U.S. Supreme Court ruling, that there was a compensable taking for the time that the regulation was in effect.

Nollan v. California Coastal Commissiom, 483 U.S. 825 (1987) and Dolan vi. City of Tigard, 114 S.Ct. 2308 (1994) are similar in that they both involve exactions imposed on property owners as a condition for the approval a permit. In Nollan the court determined that there must be a nexus between the legitimate state interest, and the exaction. The Dolan court relied on this when it found that there was no nexus between the purpose of flood control, and the requirement to deed floodplain property to the city. Such an exaction would amount to a taking. This decision cited Pennsylvania Coal, stating that "a strong public desire to improve the public condition is not enough to warrant achieving the desire by a shorter cut than the constitutional way of paying for the change." 
While there may be some apparent contradictions in the decisions rendered by the courts in takings cases, it is possible to extract an understanding of the current state of federal law regarding this issue. There has been an evolution away from the requirement that a compensable taking involve the acquisition or occupation of property. This evolution away from the rule in Mugler is first seen in Pennsylvania Coal; and the contradiction between Mugler and Lucas was explained away by introducing nuisance law into the mix. The courts seem to be taking the words of Justice Holmes literally in finding that regulation that goes "too far" amounts to a taking, rather that a due process violation. This is seen in First English and Lucas.

The Supreme Court has established four rules for determining when a taking has taken place (APA 1997): (1) where the landowner has been denied "all economically viable use" of the land; (2) where the regulation forced the landowner to allow someone else to enter onto the property; (3) where the regulation imposes burdens or costs on the landowner that do not bear a "reasonable relationship" to the impacts of the project on the community; and (4) where government can equally accomplish a valid public purpose through regulation, or through a requirement of dedicating property, and the more intrusive measure is chosen.

This has important implications for land use and environmental regulation. As this paper addresses, there is a property rights/Wise Use movement in this country aimed at requiring government compensation for the loss of property values resulting from governmental regulation. The most extreme argument is that any loss of value should be compensated. It seems that the drift of the Supreme Court toward requiring compensation over the last few years has not been fast enough. or gone far enough for the 
property rights movement. Some states have enacted laws that require compensation after a certain percentage of value is lost, or have specifically defined what constitutes a "taking." This takes the determination of what amounts to a taking out of the courts" jurisdiction, possibly resulting in more certainty in some respects. However, it is also possible that these actions will result in more contention, particularly in the determination of levels of compensation to be awarded in individual cases.

\section{CONCLUSSION}

\section{The Planning Context}

The bottom line is that having an understanding of the current status of takings law is of extreme importance to planners. As the law stands now, the U.S. Supreme Court has given ample breathing room for government regulation in pursuit of land use and environmental regulation (Kayden 1996b). However. over the past several decades there has been a narrowing of the limits to which regulation will be allowed to go. And with the current push of the Wise Use movement and takings bills in almost every state, planners should expect that there will be further change. This change will define what planners' roles will be. As expressed by Strong et al. (1996: 15), planners "know how to manage an orderly process of change, and because they have an enormous stake in the credible and effective operation of the land-use control system, planners should lead the effort to reform the regulatory system." 


\section{Chapter 3}

\section{MeTHODOLOGY}

\section{INTRODUCTION}

This chapter provides an accounting of the research and analysis methods used for this research project. Each part of the project will be discussed separately. The research project began with limited background research resulting in the formulation of the hypotheses which are discussed in Chapter 1, and then the presentation of a research proposal. The research performed and this project were based on that proposal.

\section{BACKGROUND}

The Background chapter is essentially the literature review for the research project. The research for this project began with an examination of the relevant literature regarding the Wise Use / private property rights movement, takings legislation. and any identified relationship to the state regulatory regime. This review of the literature continued throughout the course of the research project. The sources of information included professional and academic journals. books on Wise Use, and information gathered from the Internet. The Background chapter focuses on three topics, the Wise Use movement. previous research. and constitutional takings. 


\section{Wise Use}

I conducted extensive research into the Wise Use movement as a national

phenomenon, examining the movement from its early beginnings to the present, relying on journal articles and books written on the subject. The types of groups that fall under the umbrella of Wise Use, and the strategies they use to further their cause are discussed.

\section{Previous Research}

I examined research that had been done on the subject of Wise Use and takings legislation. This involved consulting academic articles and information posted on the Internet, including the American Planning Association web page (APA 1997).

\section{Constitutional Takings}

I conducted research on the legal issues surrounding the Wise Use and takings issues. I researched the case law and provide a comprehensive summary of the current state of takings law.

\section{ANALYSIS OF STATE PLANNING AND ENVIRONMENTAL STATUTES}

Chapter 4, Examination of the States, provides the data and analysis on state planning and environmental statutes and state takings legislation. These analyses are combined to provide an understanding of the relationship between state regulatory regimes and the prevalence of takings legislation proposed in the states. Six states were chosen for the research based on their varied geographic location and the ability to acquire text of legislation. These states include Kansas, Maine. Mississippi, Montana, Oregon, and Rhode Island. which represent the varied regions of the country. Rhode Island was chosen 
primarily because this research was conducted at the University of Rhode Island. and was funded by the Rhode Island Agricultural Experiment Station.

My research began by looking at the planning and environmental statutes in the six states. Information on the types of statutes in place in each of the states was located at the Rhode Island Superior Court Law Library in Providence. Rhode Island. The library maintains current copies of the general laws for each of the fifty states. I gathered information on the current status of planning, zoning, and environmental legislation in each state. These data were supplemented by information available from the American Planning Association (APA 1997).

My analysis was limited to several specific items of interest, including: levels of government at which planning takes place; whether local planning is mandatory: whether zoning must be consistent with a comprehensive plan; whether state review of comprehensive plans is required: type of subdivision regulation; whether there is endangered species protection: and the type of wetland regulation, if any. These items of interest were chosen as indicators of the strength of planning and environmental regulation in the states. A score was awarded in each category, and then a total score calculated for each state. I used this total score to categorize the states into regulatory regimes. Three categories were established based on the scores: weak, intermediate, and strong regimes of regulation.

\section{ANALYSIS OF STATE TAKINGS LEGISLATION}

Six states were researched and categorized (Kansas. Maine. Mississippi, Montana, Oregon, Rhode Island) based on the property rights bills that have been introduced in 
each of the state legislatures. They were characterized in terms of the strength of the bills and the number of bills introduced. An attempt was made to obtain the text of all takings bills introduced in each of the six states. In some states there were many more bills introduced between 1992-1996 than I was able obtain the text for. Also, the total number of bills introduced that is reported is based on the research of ARIN (1996), and is therefore subject to the accuracy of that research. Obtaining the text of bills was accomplished by contacting the Secretary of State and other officials in each state. Also acquired was the outcome of each bill. For those bills that reached a floor vote in the state legislature roll call votes were also acquired.

Each of the bills for which the text was available was analyzed. My examination of the bills was based on the typologies developed by Emerson (1996) and Thomas (1996). Basic information. such as the year the bill was introduced, the bill number, the outcome, and the parties required to act if the bill was enacted is provided. Bill strength was based on the type of bill (preliminary, assessment, or entitlement), based on Emerson`s (1996) classification. Also considered was whether a new legal standard defining a taking was established, and whether a new review process was created. Scores for each bill were totaled, and average scores for each state were also determined as a means of comparison. These averages were calculated using only those bills that were analyzed. The total number of bills introduced was not used in the calculations, because I was not able to compute a score for all of the bills introduced. These data are presented in tabular form in Chapter 4.

In Chapter 4, several analyses based on the characteristics of the bills are presented. First. a chi square analysis was conducted to determine if there was a statistically 
significant relationship between the type of bill (preliminary, assessment, entitlement) introduced and its eventual outcome (died. vetoed. enacted). The chi square test was chosen as a way of determining the relationship between two sets of nominal data.

Results of these analyses are provided in Chapter 4 . Next, two additional chi square analyses were conducted in which some of the categories were combined. This resulted in two categories of outcome, enacted and not enacted.

Next. I conducted an in-depth examination of one bill from each of the six states. These were the most recent bills introduced in each of the states. Each bill, except for the Rhode Island bill, was passed by the legislature, and was either enacted or vetoed by the governor. The discussion of the bills provides insight into the development of takings bills, and how they differ from state to state.

As with the environmental and planning regulation. I also categorized the states based on the regime of takings legislation. For each state the average strength of the bills introduced, as discussed above. combined with the total number of bills introduced produced a total score. These scores were then used to compare the six states as to their proclivity toward takings legislation.

\section{CORRELATIONS BETWEEN REGULATORY AND LEGISLATIVE REGIMES}

Next. with the analysis of the regulatory regimes and takings legislation in the states completed, I determined the strength of correlation between these two variables. For this analysis the independent variable is the data resulting from the analysis of the states" regulatory regimes. The dependent variable is represented by the regime of takings legislation in each of the states. Using these data to represent each variable, the 
relationship between the independent variable, state regulatory regime. and the dependent variable, the prevalence and strength of state takings legislation was identified.

With the data gathered from the six states I performed chi square analyses to determine the nature of the relationship that existed between the regulatory regime in the states and the introduction of takings legislation. As with previous analyses, the chi square analysis was chosen in order to determine whether there was a statistically significant relation between the independent and dependent variables. I conducted an analysis to determine the strength of relationship between state regulatory regime and the number of bills enacted in the states.

Next, in order to determine the relationship between the regulatory regime in each state and the regime of takings legislation. I used the Spearman's rho technique of statistical analysis. This type of analysis allowed the comparison of the states based on rankings. First, the states were ranked based on the strength of their regulatory regime. The states were also ranked based on the number of bills introduced in the legislatures. These rankings were then analyzed using the Spearman`s rho formula. These analyses are provided in Appendix A. A Spearman's rho analysis was also conducted on the rankings of state regulatory regime and the average strength of bills introduced in the states. Next. in a combination of the two prior analyses. a Spearman's tho analysis was also conducted on regulatory regime and legislative regime in the states. As discussed earlier, the state legislative regime is a combination of the average strength of bills combined with the number of bills introduced. The result here represents the relationship between the regulatory regime of the state and the number of bills introduced. 
The final statistical analysis was a chi square test to determine if there was a relationship between the strength of the bills enacted and the regulatory strength of the states where they were enacted. Again, the chi square was chosen in order to determine the relationship between these nominal variables.

\section{A CASE STUDY OF RHODE ISLAND}

In providing a case study of the State of Rhode Island, a wide variety of sources of information were used in order to construct a portrait of the State in terms of land use and environmental regulation, and the status of the Wise Use movement. The Case Study of Rhode Island is presented in Chapter 5.

\section{Regulatory Regime}

First, research into the planning regulations that are in effect in Rhode Island focused on planning, zoning, and subdivision regulation. For this section I also relied on personal experience with regulation in the state, supplemented by description and commentary from other sources, and research of the Rhode Island General Laws. Chapter 5 also provides a comprehensive view of this regulation. Next, the discussion of environmental regulation in the state is based on my own understanding and experience with the Rhode Island system. This was supplemented with information gathered through research of the Rhode Island General laws and other sources.

\section{Takings Legislation}

The discussion of takings legislation is an expansion of the information provided in Chapter 4 . In addition to the information on the number and types of bills introduced in the state legislature. Chapter 5 presents a great deal of interesting anecdotal information 
gathered from key players in the takings debate. These include the leader of the Rhode Island Wise Movement. Brian Bishop, and the Director of the Rhode Island Department of Environmental Management (RIDEM). Also the perspective of a State Senate Legislative Analyst is presented to give insight into the current situation and prospects for the future of the property rights debate in Rhode Island.

Chapter 5 also presents research conducted into the Rhode Island Constitution, in order to determine how the issue of private property and takings is currently addressed. Of particular interest was an amendment that was added to the constitution after the 1986 Constitutional Convention. This amendment provided protection to landuse and environmental regulations against claims of takings. The amendment, and the politics surrounding its adoption are presented in Chapter 5.

\section{Rhode Island Wise Use}

An in-depth examination of Rhode Island Wise Use, the primary property rights advocacy group in the state, is provided. Information for this discussion was gained through communications with the leader of RI Wise Use. Brian Bishop, and from my attendance at one of the group's meetings. Andrew McLeod, Director of RIDEM. was the guest speaker at this meeting. It was at this meeting that I gained some perspective into the Director's view of RI Wise Use, and property rights issues in general. The meeting provided an opportunity to meet members of RI Wise Use, and to get their input on the issues. 


\section{RI Department of Environmental Management}

The final section of Chapter 5 provides a look at the role RIDEM has played in the property rights and Wise Use debate. The sources of information for this section were primarily newspaper articles reporting on recent controversial cases involving RIDEM.

\section{CONCLUSION}

In conducting the research for this project a variety of sources of information, and various methods of analysis were used. This combination has produced a complete. well rounded, and significant piece of research which sheds light on the Wise Use movement and takings legislation nationally, and in Rhode Island. 


\section{Chapter 4}

\section{EXAMINATION OF THE STATES}

\section{INTRODUCTION}

This chapter examines the regulatory regimes and takings legislation regimes in six states: Kansas, Maine, Mississippi, Montana, Oregon, and Rhode Island. It will provide an inventory and classification of the planning and environmental regulatory regime in each state. and rank the states according to this regime. Next it will provide an inventory of the takings legislation that has been introduced in each of the six states, including a typology of the types of legislation and the status of each bill. Bills from each state will be discussed in more depth to provide examples of the various types of legislation that have been introduced. Finally, the chapter provides analysis of state regulatory regimes and the number and type of takings bills introduced in each state to determine if there is a correlation between these factors.

\section{ANALYSIS OF STATE PLANNING AND ENVIRONMENTAL STATUTES}

\section{Typology of Statutes}

In order to classify each of the six states by their regulatory regimes I have researched the planning and environmental statutes. The factors of planning regulation focused on included: the levels of government at which planning takes place; whether local planning 
(city or county) is mandatory; whether there is a consistency requirement between

comprehensive planning and zoning; whether state review of comprehensive plans is

required: and whether subdivision regulation is mandatory. In order to get an indication of

the environmental regulatory regime in each state I focused on endangered species

protection and wetlands regulation.

Table 4-1 State Planning, Zoning, and Environmental Regulations

\begin{tabular}{|c|c|c|c|c|c|c|c|c|}
\hline State & $\begin{array}{l}\text { Levels of } \\
\text { Planning }\end{array}$ & $\begin{array}{l}\text { Score } \\
(2-4)\end{array}$ & $\begin{array}{l}\text { Mandatory/ } \\
\text { Empowered } \\
\text { Planning (local) }\end{array}$ & $\begin{array}{c}\text { Score } \\
(1-2)\end{array}$ & $\begin{array}{l}\text { Comp Plan } \\
\text { Required for } \\
\text { Zoning } \\
\text { /consist. }\end{array}$ & $\begin{array}{c}\text { Score } \\
(0-1)\end{array}$ & $\begin{array}{l}\text { State } \\
\text { Review of } \\
\text { Comp } \\
\text { Plan }\end{array}$ & $\begin{array}{l}\text { Score } \\
(0-1)\end{array}$ \\
\hline Kansas & $\begin{array}{l}\text { municipality, } \\
\text { counties (1) }\end{array}$ & 2 & empowered & 1 & no(2) & 0 & no & 0 \\
\hline Maine & $\begin{array}{l}\text { municipality, } \\
\text { region, state }\end{array}$ & 3 & empowered & 1 & yes & 1 & yes & 1 \\
\hline Mississippi & $\begin{array}{l}\text { municipality, } \\
\text { regional, county }\end{array}$ & 3 & empowered & 1 & yes & 1 & no & 0 \\
\hline Montana & $\begin{array}{l}\text { municipal, } \\
\text { county }\end{array}$ & 2 & empowered & 1 & no & 0 & no & 0 \\
\hline Oregon & $\begin{array}{l}\text { municipal, } \\
\text { county, region, } \\
\text { state }\end{array}$ & 4 & mandatory & 2 & yes (4) & 1 & yes & 1 \\
\hline $\begin{array}{l}\text { Rhode } \\
\text { Island }\end{array}$ & $\begin{array}{l}\text { municipality, } \\
\text { state }\end{array}$ & 2 & mandatory & 2 & yes & 1 & yes & 1 \\
\hline
\end{tabular}

\begin{tabular}{|c|c|c|c|c|c|c|c|}
\hline State & $\begin{array}{l}\text { Subdivision } \\
\text { Regulation } \\
\text { Allowed }\end{array}$ & $\begin{array}{l}\text { Score } \\
(0-2)\end{array}$ & $\begin{array}{l}\text { State Endangered } \\
\text { Species Protection }\end{array}$ & $\begin{array}{c}\text { Score } \\
(0-1)\end{array}$ & $\begin{array}{l}\text { State Wetland } \\
\text { Regulation }\end{array}$ & $\begin{array}{c}\text { Score } \\
(0-2)\end{array}$ & $\begin{array}{l}\text { TOTAL } \\
\text { SCORE }\end{array}$ \\
\hline Kansas & $\begin{array}{l}\text { allowed: muni, } \\
\text { county(3) }\end{array}$ & 1 & yes (32-957) & 1 & no & 0 & 5 \\
\hline Maine & mandatory & 2 & $\begin{array}{l}\text { yes (title 12, sec. } \\
7751 \text { ) }\end{array}$ & 1 & $\begin{array}{l}\text { yes (title 12, } \\
\text { sec. 4751) }\end{array}$ & 2 & 11 \\
\hline Mississippi & $\begin{array}{l}\text { allowed: } \\
\text { municipality, } \\
\text { county }\end{array}$ & 1 & yes (sec. 45-5-101) & 1 & $\begin{array}{l}\text { coastal } \\
\text { wetlands only } \\
\text { (sec. 49-27-1) }\end{array}$ & 1 & 8 \\
\hline Montana & allowed & 1 & yes $(87-5-1)$ & 1 & no & 0 & 5 \\
\hline Oregon & mandatory & 2 & yes (sec 496) & 1 & yes (sec 196) & 2 & 13 \\
\hline $\begin{array}{l}\text { Rhode } \\
\text { Island }\end{array}$ & mandatory & 2 & yes (Sec. 20-37-2) & 1 & $\begin{array}{l}\text { yes (Sec. 2-1- } \\
20)\end{array}$ & 2 & 11 \\
\hline
\end{tabular}

(1) Designated urban counties may also create township planning boards, plans.

(2) Based on my review, no requirement, however, zoning amendments consistent with comp plan are presumed to be reasonable.

(3) Cities have power to zone and regulate subdivisions outside city, with in 3 miles of boundary, subject to restrictions.

(4) Local plans and ordinances must also be consistent with state planning goals.

Source: State Statutes; APA (1996)

The findings of this research, and the scoring and rank of each state's overall regulatory regime are provided in summary form in Table 4-1. According to this analysis 
Maine. Oregon, and Rhode Island have the stronger regulatory regimes, while Kansas,

Mississippi, and Montana have weaker regimes.

Based on a review of its statutes, Kansas intervenes little in property regulation. It has no laws or procedures at the state level for environmental impact statement (EIS) preparation or wetlands regulation. It does not mandate local planning or zoning, nor does it provide state oversight of local planning. Kansas authorizes municipal and county zoning and subdivision control. subject to prior preparation of a comprehensive plan (KSA $\$ 12-747: \$ 12-753)($ Pendall et al. 1997).

Based on a review of its statutes, Maine along with Oregon, is one of the most active states in regulation of property. Maine has a State Planning Office that formulates resource management plans for major rivers and coastal areas and oversees development in unincorporated areas ( 12 MRS $\$ 683$ ff.). The Maine Department of Environmental Protection issues permits for developments of regional impact under the Site Location of Development Law (38 MRS $\$ \$ 481-90$ ), has authority to regulate alteration of coastal wetlands (12 MRS $\$ \$ 4753-4754$ ), and may reject local zoning and land-use laws for shoreline areas and superimpose its own regulations. In 1989, Maine adopted a state growth management program that included mandates for municipal plan preparation. However, the state legislature repealed this provision in 1991; municıpalities are now authorized, but not required, to prepare comprehensive plans and zoning ordinances (30A MRS $\$ 4301 \mathrm{ff}$.). Local subdivision review remains mandatory (30A MRS $\$ 4404$ ). Thus Maine exercises substantial control over property at the state level, but incorporated towns and cities may, if they wish, exercise very little control over property (Pendall et al. 1997). 
Mississippi has few statutory provisions for environmental protection or development regulation. At the state level, there is no legislation on wetlands, endangered species protection, or environmental impact statements. Counties and municipalities are authorized to develop comprehensive plans; if they do so, they are required to prepare zoning ordinances and subdivision regulations (Pendall et al. 1997).

Montana exercises modest levels of environmental control at the state level, according to a review of its statutes. It is one of 15 states that currently has an environmental impact statement mandate. which applies to state agencies but not local governments. It is, in fact, this statute-the Montana Environmental Protection Act, or MEPA-that was amended by SB 231. which is discussed below. In addition to MEPA, the state of Montana authorizes but does not require local and county comprehensive planning and zoning ( $\$ \$ 76-1-106,7-1-2104)$; it does, however, mandate local review of subdivisions of land into parcels of 160 acres or less (MCA \$76-3-104, 601). Generally, in Montana there is no strong state or local regulatory threat to private property rights (Pendall et al. 1997).

As mentioned above, Oregon is widely recognized as a leader in planning and environmental protection. Its statewide growth management program (ORSA $\$ 197.005$ to 020) establishes goals for environmental protection, promotion of compact urban development patterns, and integrity of resource lands, among other objectives. Regions and cities are required to adopt urban growth boundaries (UGBs) to accommodate 20 years of expected growth. Inside the UGB. localities are required to facilitate development: outside, development occurs at much lower intensities. Cities and counties are required to develop comprehensive plans that are consistent with the state goals and to adopt zoning ordinances and subdivision regulations that implement their comprehensive 
plans (ORSA $\$ \$ 197.175,227.010$ et seq.. 92.010 et seq.). The growth management program has survived three statewide referenda with constant support from environmentalists, and support from homebuilders and the forest products industry. both of which have benefited from the enhanced certainty created by UGBs. The state also has special legislation to protect wetlands (\$196.600 et seq.)(Pendall et al. 1997).

Rhode Island is also recognized as a leader in planning and growth management (Meck 1997). There are three essential pieces of state enabling legislation, that combined make up the state planning regime. First is the Comprehensive Planning and Land Use Regulation Act of 1988 (RIGL Section 45-22.2-2). A new zoning enabling act, which applies to all communities was passed in 1991 (RIGL Section 45-24-2). The third and final piece of Rhode Island's planning regulatory framework is development regulation. The Land Development and Subdivision Review Enabling Act was passed in 1992 (RIGL Section 45-23-1). Again, these regulations apply to all 39 cities and towns in the state. Rhode Island is discussed in more depth in Chapter 5.

\section{State Regulatory Regimes}

Based on the typology of the states and the scoring in Table 4-1, I have devised three regulatory regimes as a way if classifying each of the states. All of the states studied have some form of endangered species legislation, therefore this was not a factor.

\section{Weak Regime}

Those states that scored five or fewer points in Table 4-1 are identified as having a weak regime of land use and environmental regulation. Of the six states examined. Kansas and Montana had the weakest regimes: zoning consistent with a comprehensive plan was not required; no State review of comprehensive plans was required: local 
subdivision regulations were not required; there was no state wetland regulation; and planning at the local level was not mandatory.

\section{Intermediate Regime}

Those states with scores from six to nine are considered to have intermediate strength regimes of regulation. The State of Mississippi falls into this catagory: planning at the local level was not mandatory; zoning consistent with a comprehensive plan was required: and there was State wetland regulation for coastal wetlands only.

\section{Strong Regime}

Those states with scores of ten or higher are considered to have strong regimes of land use and environmental regulation. Of the states examined, Maine. Oregon, and Rhode Island fall into this category: planning at the local level was mandatory (except in Maine); zoning consistent with a comprehensive plan was required; state review of comprehensive plans was also required; local subdivision regulation was required: and there was state-level wetland regulation.

\section{ANALYSIS OF STATE TAKINGS LEGISLATION}

\section{Typologies of Legislation}

As discussed in the previous chapter, the focus of this research is on the actions taken by the wise use movement in an attempt to implement new laws and policies in state government that would address the concerns of property owners impacted by regulations. Takings bills can be distinguished over a range of strength. This research indicates that in the six states studied, the majority of bills introduced are of the strongest variety, however 
these bills are less likely to be enacted. Although, some states have enacted stricter provisions.

\section{Bills in the Six States}

I have analyzed the bills in each of the six states using a combination of the typologies developed by Emerson (1996) and Thomas (1996). Table 4-2 provides a listing of the bills introduced in each of the six states since 1992, with a ranking of the bills based on my typology.

\section{Summaries of legislation}

Next are summaries of bills from each of the states. Except for the Rhode Island bill. each of these bills reached a vote in the legislature and passed. The bills were then either enacted or vetoed by the respective governor. These summaries give a representative sampling of the types of legislation that have been adopted by state legislatures in different parts of the country, and with different regimes of regulation. Because the Rhode Island bill did not emerge from committee and did not reach a vote, it is examined here for the purpose of comparison only.

Kansas Senate Bill 293, "The Private Property Protection Act" (1994)

Kansas Senate Bill 293 (SB293) was passed by substantial margins in both the House and the Senate in 1994, however, the bill was vetoed by the governor. The House voted $88-37$ in favor, and the Senate voted $33-7$ in favor. The purpose of the bill was 
Table 4-2 State Takings Legislation

\begin{tabular}{|c|c|c|c|c|c|c|c|c|c|c|c|c|c|}
\hline State & Year & $\begin{array}{l}\text { Bill } \\
\text { Number }\end{array}$ & Outcome & $\begin{array}{c}\text { Parties } \\
\text { required to } \\
\text { act }\end{array}$ & Bill Type(1) & $\begin{array}{l}\text { Score } \\
(1-3)\end{array}$ & $\begin{array}{l}\text { New } \\
\text { Standard for } \\
\text { Taking? (2) } \\
\end{array}$ & Score (1-2) & $\begin{array}{c}\text { New review } \\
\text { process } \\
\text { created? }\end{array}$ & $\begin{array}{l}\text { Score } \\
(0-1)\end{array}$ & $\begin{array}{l}\text { Total } \\
\text { Score }\end{array}$ & $\begin{array}{l}\text { Average } \\
\text { for State }\end{array}$ & $\begin{array}{c}\text { Number of } \\
\text { Bills (3) }\end{array}$ \\
\hline Kansas & 1994 & SB293 & $\begin{array}{l}\text { enacted } \\
\text { vetoed }\end{array}$ & $\begin{array}{l}\text { Attorney } \\
\text { General, } \\
\text { State } \\
\text { Agency } \\
\text { State } \\
\text { Agency }\end{array}$ & 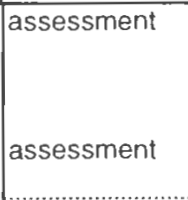 & 2 & no & 1 & yes & 1 & 4 & 4 & 2 \\
\hline Maine & $\begin{array}{l}1996 \\
1995 \\
1993\end{array}$ & $\begin{array}{l}\text { HB1 } 188 \\
\text { LD1217 } \\
\text { LD170 } \\
2 \text { bills int }\end{array}$ & $\begin{array}{l}\text { enacted } \\
\text { enacted } \\
\text { died } \\
\text { oduced, fur }\end{array}$ & $\begin{array}{l}\text { Land owner, } \\
\text { State } \\
\text { Agency } \\
\text { Study } \\
\text { Commission } \\
\text { Property } \\
\text { Owner, Govt. } \\
\text { Agency } \\
\text { ther informatio }\end{array}$ & 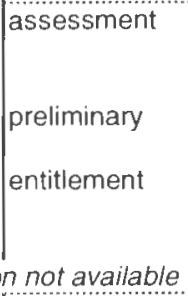 & $\begin{array}{l}1 \\
3\end{array}$ & $\begin{array}{l}\text { no } \\
\text { yes }\end{array}$ & $\begin{array}{l}1 \\
2\end{array}$ & $\begin{array}{l}\text { no } \\
\text { no }\end{array}$ & $\begin{array}{l}0 \\
0\end{array}$ & $\begin{array}{l}2 \\
5\end{array}$ & 3.3 & 5 \\
\hline Mississippi & 1994 & $\begin{array}{l}\text { HB1541 } \\
\text { HB816 } \\
\text { HB858 } \\
\text { SB2117 } \\
\text { SB2464 }\end{array}$ & $\begin{array}{l}\text { enacted } \\
\text { died } \\
\text { died } \\
\text { died } \\
\text { enacted }\end{array}$ & $\begin{array}{l}\text { Property } \\
\text { owner } \\
\text { Property } \\
\text { owner, Govt. } \\
\text { agency } \\
\text { Property } \\
\text { owner, Govt. } \\
\text { agency } \\
\text { Property } \\
\text { Owner } \\
\text { Property }\end{array}$ & $\begin{array}{l}\text { entitlement } \\
\text { entitlement } \\
\text { entitlement } \\
\text { entitlement } \\
\text { entitlement }\end{array}$ & $\begin{array}{l}3 \\
3\end{array}$ & $\begin{array}{l}\text { yes } \\
\text { yes }\end{array}$ & $\begin{array}{l}2 \\
2\end{array}$ & $\begin{array}{l}\text { no } \\
\text { yes }\end{array}$ & $\begin{array}{l}0 \\
1\end{array}$ & $\begin{array}{l}5 \\
6\end{array}$ & 5.4 & 5 \\
\hline Montana & 1995 & HB597 & $\begin{array}{l}\text { enacted } \\
\text { enacted }\end{array}$ & $\begin{array}{l}\text { n/a } \\
\text { Attorney } \\
\text { General, } \\
\text { State } \\
\text { Agency } \\
\text { Govt. } \\
\text { Agency, } \\
\text { Property } \\
\text { Owner } \\
\text { Govt. } \\
\text { Agency }\end{array}$ & entitlement & $\begin{array}{l}1 \\
2\end{array}$ & $\begin{array}{l}\text { no } \\
\text { no }\end{array}$ & $\begin{array}{l}1 \\
1\end{array}$ & $\begin{array}{l}\text { no } \\
\text { yes }\end{array}$ & $\begin{array}{l}0 \\
1\end{array}$ & $\begin{array}{l}2 \\
4\end{array}$ & 3.8 & 4 \\
\hline
\end{tabular}




\section{Table 4-2 State Takings Legislation (continued)}

\begin{tabular}{|c|c|c|c|c|c|c|c|c|c|c|c|c|}
\hline Oregon & $\begin{array}{r}\text { SB1081 } \\
\text { HB2122 } \\
\text { HB2504 } \\
19935 \text { bills int }\end{array}$ & $\begin{array}{l}\text { died } \\
\text { died } \\
\text { died } \\
\text { duced, } f\end{array}$ & $\begin{array}{l}\text { Property } \\
\text { owner, govt. } \\
\text { agency } \\
\text { Property } \\
\text { Owner, Govt. } \\
\text { Agency } \\
\text { Property } \\
\text { Owner, Govt. } \\
\text { Agency } \\
\text { Property } \\
\text { Owner, Govt. } \\
\text { Agency } \\
\text { ther informatio }\end{array}$ & $\begin{array}{l}\text { entitlement } \\
\text { entitlement } \\
\text { entitlement } \\
\text { entitlement }\end{array}$ & 3 & yes & 2 & no & 0 & 5 & 5.3 & 9 \\
\hline $\begin{array}{l}\text { Rhode } \\
\text { Island }\end{array}$ & $\begin{array}{l}1996 \text { HB7868 } \\
\\
1995 \text { HB5241 } \\
\text { SB360 } \\
\text { SB509 } \\
1994 \text { 3 bills int } \\
1993 \text { 3 bills int }\end{array}$ & $\begin{array}{l}\text { died } \\
\text { further i } \\
\text { further i } \\
\text { in comn } \\
\text { duced, } f \\
\text { duced, } f\end{array}$ & $\begin{array}{l}\text { Attorney } \\
\text { General, } \\
\text { State } \\
\text { Agency } \\
\text { ormation not a } \\
\text { ormation not a } \\
\text { ttee } \\
\text { ther informatio } \\
\text { ther informatio }\end{array}$ & $\begin{array}{l}\text { assessment } \\
\text { ivailable } \\
\text { ivailable } \\
\text { in not available } \\
\text { n not available }\end{array}$ & 2 & no & 1 & yes & 1 & 4 & 4 & 10 \\
\hline
\end{tabular}

(1) Based on Emerson 1996

(2) Other than current law or the 5 th and 14 th Amendments to the U.S. Constitution or similar state constitutional provisions

(3) Includes bills for which information was not available.

Sources: ARIN 1996; Bill text and votes provided by each state. 
to "reduce the risk of undue or inadvertent burdens on private property rights resulting from certain lawful government actions." The bill would have required state agencies to submit a written report on the justification for, and the takings implications of the action. The bill would have required that the report on takings implications be made public prior to any government action restricting private property use. The report would have to identify: the public health or safety risk created by the use of the private property; how the proposed action would protect public health and safety: present facts that show the restriction is "proportionate" with the need for the restriction; analyze the likelihood that the government action would result in a constitutional taking; and identify alternatives to the government action.

The standard used for determining when a taking had occurred would have been the Fifth and Fourteenth amendments to the U.S. Constitution or Section 18 of the bill of rights in the Constitution for the State of Kansas. There were no consequences prescribed for a violation of the act, and no payment to property owners impacted by a government action was authorized.

Maine LD 1217 "Establishing the Study Commission on Property Rights and the Public Health, Safetr and Welfare" (1995)

Maine bill LD1217 was enacted in 1995 after it passed both the House and the Senate by wide margins: $129-14$ in the House, and 28-6 in the Senate. The purpose of the bill was to establish a study commission to report to the legislature on the issue of constitutional property rights protections, and to answer several questions: Is there credible evidence that state and municipal governments have engaged constitutional takings? Do specific state or local laws pose an unconstitutional burden on property 
owners? Are there unreasonable delays in the adjudication of compensation claims? Should statutory cause of action be created for property owners? Can pursuit of takings claims be made less costly and more expeditious for property owners? If the state creates a cause of action for property owners against government entities, should one be created against non-government entities? How would proposed takings law affect the court system?

While this bill, in itself, did not create new standards for a taking, or a new review process, ultimately the commission did present recommendations. In 1996 the legislature passed, and the Governor signed LD 1629, "An Act to Implement the Recommendations of the Study Commission on Property Rights and the Public Health, Safety and Welfare Establishing a Land Use Mediation Program and Providing for Further Review of Rules." This legislation established a land use mediation program whereby a land owners can apply for mediation if the land owner "has suffered significant harm as a result of a governmental action regulating land use." This program is meant to be an alternative to court action. Perhaps more significantly, the legislation also provides for attorney general review of proposed rules to determine the potential for a taking. A rule that is "reasonably expected to result in a taking of private property" may not be approved unless there are variance procedures provided to avoid a taking. The voting data for this legislation was not available at this writing.

Mississippi Senate Bill 2464, "Mississippi Forestry. Activiţ. Act" (1994)

Mississippi Senate Bill 2464 (SB2464) was passed by a substantial margin in the legislature and enacted in 1994. The House vote was 94-27, and the Senate vote was 520 . The purpose of the bill was to establish a policy "allowing owners of property 
classified as forest land and owners of timber, wood and forest products on forest land owned by another to conduct forestry activities. or if the State of Mississippi prohibits or severely limits such forestry activities, to compensate the owners for their loss." The bill also stated that a nuisance action brought against an agricultural operation. including forestry, which had been in operation for one (1) year or more would be essentially void. The agricultural operation would have an "absolute defense."

The standard for a taking, as defined in the bill, is any action taken by the State under the Fifth and Fourteenth Amendments to the U.S. Constitution. or Article III, Section 17 of the Mississippi Constitution where the owner is entitled to compensation. Therefore the act relies on existing law for the taking definition. However, the bill relies on "inverse condemnation" and defines it somewhat differently: "any action by the State of Mississippi that prohibits or severely limits the right of the owner to conduct forestry activities on forest land." This definition excludes a "taking" as defined, and any police power action to protect public health and safety from activities that are "noxious in fact". which are those that constitute a public nuisance under common law.

The bill gives the right of action to a property owner to bring a claim of inverse condemnation against the State for any action that constitutes an inverse condemnation of forest land, timber, wood or forest products, including non-game species or personal property rights associated with conducting forestry activity. The bill authorizes payment of compensation where a court finds that an inverse condemnation has taken place. 
Montana Senate Bill 231, "An act revising the parpose and policy of the Montana Envirommental Policy Act to include private property right considerations and impacts of state government actions." (1995)

Montana Senate Bill 231 (SB231) was passed by the legislature and enacted in 1995. The House vote was $75-23$ and the Senate vote was $48-2$. This bill was an amendment to the Montana Environmental Policy Act with the purpose of adding language to the effect that "whenever Montana Environmental Policy Act analysis is required, it is the intent of the legislature that actions that regulate the use of private property are evaluated to ensure that alternatives that reduce, minimize, or eliminate regulatory restrictions are considered." It is further stated that purpose is to "declare a state policy that will encourage productive and enjoyable harmony between humans and their environment. to protect the right to use and enjoy private property free of undue government regulation..." The amendments also add language to the policy statements of the Act. including: “. . . and further recognizing that government regulation may unnecessarily restrict the use and enjoyment of private property. . " The bill also added to the list of responsibilities of the state: to "protect the right to use and enjoy private property free of undue government regulation." This is essentially a policy bill, and therefore offers no new procedures, or reviews. There is no discussion of compensation of property owners.

Montana House Bill 311. "Private Property Assessment Act" (1995)

Montana House Bill 311 (HB311) was passed by large margins in both the House and Senate and was enacted in 1995. The House vote was 98-0, and the Senate vote was 3911. The purpose of this bill was to "establish an orderly and consistent process that better enables state agencies to evaluate whether an action with taking or damaging implications 
might result in the taking or damaging of private property." A taking is defined as "depriving a property owner of private property in a manner requiring compensation under the $5^{\text {th }}$ and $14^{\text {th }}$ amendments to the constitution of the United States or Article II, section 29. of the Montana constitution." This bill relies on current law, and does not propose a new standard for taking.

The bill charged the attorney general with developing guidelines for state agencies to assist in determining the taking implications of regulations. It also requires agencies to assign personnel to conduct impact assessments on regulations. Agencies can not enact a regulation until the assessment is completed. The assessment must include: a determination of the likelihood that a court would find the action to be a taking: alternatives to the action that would fulfill the agency's statutory obligation: and an estimated cost of compensation that the state agency would be required to pay, and the source for the payment of compensation if there is a taking. There is no compensation of property owners authorized by this bill. It appears to be strictly an assessment bill. This bill went a step further than SB 231 in that it required action on the part of State officials. SB 231 simply added language to policy statements..

Oregon Senate Bill 600 "Relating to impacts of regulation on private real property"(1995)

Oregon Senate Bill 600 (SB600) was passed by both the House and the Senate in 1995, but vetoed by the governor. The House vote was 32-26, and the Senate vote was 18-9. The purpose of the bill, stated explicitly, was to prohibit the state or local governments from enacting "eco-take" legislation. An eco-take is defined as an enactment that results in a restriction, or affirmative obligation pertaining to the use of private real 
property that has the effect of protecting, providing for or preserving any eco resource.

The regulating entity would have had to issue public notice that a proposed action was expected to cause an eco-take, and if not exempt, would have to certify that: a) the enactment is not an eco-take, b) the enactment is an eco-take but exempt. or c) the enactment is an eco-take that is not exempt. The burden of proof would have been on the regulating entity. A compensation system was proposed as part of the bill to compensate property owners found to be impacted by a certified eco-take.

Under this bill a new review process would have been created, and compensation to property owners was authorized. The standard for a taking was defined in the bill, and was specific to government actions that protect or preserve an eco-resource. Ecoresources include scenic areas, natural areas, open spaces, wildlife areas. wetlands, wilderness areas, outdoor recreation areas. Therefore, as with the Mississippi bill, this bill relied on a definition of taking other than the constitutional provisions cited in the other bills.

Rhode Island House Bill 96-H-7868, "The Rhode Island Private Property Rights Act" (1996)

Rhode Island House Bill 96-H-7868 died in committee and therefore there was no floor vote. The purpose of the act was to establish guidelines to assist state agencies in determining actions that may be constitutional takings, and establish guidelines for state agency action. The bill would have required the attorney general to assist state agencies in determining the guidelines. It spelled out some specific steps that must be taken before an agency action that restricts private property use for the protection of public health or safety, including: clearly identify the public health or safety risk created by the private 
property use; establish that the action substantially advances the purpose of protecting the public health and safety against the risk; establish that the restrictions on use are "reasonably proportionate" to the extent the use contributes to the risk: and estimate the potential government cost if a court finds the action to be a constitutional taking.

The standard used for determining when a taking had taken place is based on whether compensation is required under the fifth or fourteenth amendments to the U.S.

Constitution. This bill was, therefore, based on current law and did not redefine "taking." Analysis of Legislation

As described in the Chapter 3, I have conducted chi square analyses of the data presented in Table 4-2. The spread sheets for these analyses are presented in Appendix A of this document. Table 4-3 provides a summary of the types of legislation introduced and the outcome of the bills in the six states. Of a total of 19 nineteen bills analyzed, seven were enacted (approximately 37\%). As mentioned above, weaker bills are more likely to be enacted. For these nineteen bills, both preliminary bills were enacted; $50 \%$ of the assessment bills were enacted; and only $18 \%$ of the entitlement bills (the strongest type) were enacted. The entitlement bills, however, accounted for $58 \%$ of all bills introduced, and therefore represent $29 \%$ of the enacted bills. This means that although a relatively small percentage of entitlement bills pass, because a large number of such bills were introduced, they make up a substantial percentage of those bills that are enacted. 
Table 4-3 Legislative Summary

\begin{tabular}{l|ccc|c}
\hline \multirow{2}{*}{ Outcome } & \multicolumn{3}{|c}{ Bill Type (1) } \\
\cline { 2 - 4 } & preliminary & assessment & entitlement & Total \\
died & 0 & 2 & 8 & 10 \\
vetoed & 0 & 1 & 1 & 2 \\
enacted & 2 & 3 & 2 & 7 \\
\cline { 2 - 4 } & 2 & 6 & 11 & 19
\end{tabular}

(1) Based on Emerson (1996)

Source: Bill text and votes provided by each state.

I performed a chi square analysis on the data as presented in Table 4-3 in order to further document these relationships. The analysis using the data as presented above, with the disaggregated categories, indicated that the relationship between the two variables was not statistically different from what might be found with a random distribution:

Chi square (obtained) $=$ Degrees of freedom $=$ Alpha $=$

Chi square $($ critical $)=$
6.25

The next analysis combined the categories of bills that died prior to a vote and those that were vetoed (Table 4-4). This allowed the examination of the relationship between bills that were enacted and those that were not, and which types of bills were more likely to be enacted. When this was done, a statistically significant relationship between that type of bill and its outcome was found. As discussed above, the strongest bills are significantly less likely to be enacted.

Table 4-4 Legislative Analysis: Outcome vs. Type

\begin{tabular}{l|ccc|c}
\hline \multirow{2}{*}{$\begin{array}{l}\text { Outcome } \\
\text { died/vetoed }\end{array}$} & \multicolumn{3}{|c|}{ Bill Type } \\
\cline { 2 - 4 } enacted & 0 & 3 & 9 & Total \\
& 2 & 3 & 2 & 7 \\
\cline { 2 - 4 } & 2 & 6 & 11 & 19
\end{tabular}

Chi square (obtained) $=$ Degrees of freedom= 
Alpha $=\quad 0.1$

Chi square $($ critical $)=\quad 4.605$

I then condensed preliminary and assessment bills into one category and conducted the same analysis (Table 4-5). Because entitlement bills, which generally provide for compensation and create new standards for takings, represent a stronger alternative to preliminary and assessment bills it seems reasonable to combine the weaker measures.

Table 4-5 Legislative Analysis: Outcome vs. Type

\begin{tabular}{l|cc|c}
\hline \multirow{2}{*}{ Outcome } & \multicolumn{3}{|c}{ Bill Type } \\
\cline { 2 - 3 } died/vetoed & prelim/asses & entitlement & Total \\
enacted & 3 & 9 & 12 \\
& 5 & 2 & 7 \\
\cline { 2 - 3 } & 8 & 11 & 19
\end{tabular}

Chi square $($ obtained $)=$

3.909

Degrees of freedom=

Alpha=

Chi square $($ critical $)=$

2.706

Again there is a statistically significant relationship between the type of bill being considered and the outcome of the bill.

\section{State Legislative Regimes}

Table 4-6 gives a summary of the typology of takings legislation shown in Table 4-2. The six states can be categorized as to strength of takings legislation introduced. Looking at the average score of legislative strength for each state indicates that Mississippi and Oregon, on average, had the strongest legislation introduced. The other states had substantially lower average strength of legislation. with Maine being lowest.

Also, the number of bills introduced in each state is indicated in Table 4-6. Oregon and Rhode Island had the highest number of bills introduced since 1992. The other states had substantially fewer bills introduced, with Kansas having the fewest. 
Table 4-6 State Legislative Summary

\begin{tabular}{l|cc|r}
\hline \multirow{2}{*}{ Kansas } & $\begin{array}{c}\text { Average } \\
\text { strength of } \\
\text { bills }\end{array}$ & $\begin{array}{c}\text { Number of } \\
\text { Bills (1) }\end{array}$ & \multicolumn{1}{c}{ Total } \\
\cline { 2 - 4 } Maine & 4.0 & 2 & 6.0 \\
Mississippi & 3.3 & 5 & 8.3 \\
Montana & 5.4 & 5 & 10.4 \\
Oregon & 3.8 & 4 & 7.8 \\
Rhode Island & 5.3 & 9 & 14.3 \\
& 4.0 & 10 & 14.0
\end{tabular}

(1) Bills 1992-1996; Includes bills for which information was not available.

Source: ARIN; Bill text provided by the states

Table 4-6 indicates the addition of the average strength of the takings legislation introduced, to the number of bills introduced in each state. This provides a way of looking at how the states compare in the activity of takings legislation efforts. Oregon and Rhode Island have the highest scores. indicating that there is a strong effort to implement takings legislation in these states. Kansas and Montana have the lowest scores, indicating limited interest in takings legislation. The next section provides the analysis of the relationship between the regulatory regime and the legislative regime, and a comparison among the six states.

\section{CORRELATIONS BETWEEN REGULATORY AND LEGISLATIVE REGIMES}

The analysis that I first conducted in examining the relationship between state regulatory regime and takings legislation was in order to confirm that states with stronger regulation saw fewer takings bills enacted. This was a finding of Emerson (1996). The chi square analysis is depicted in Table 4-7. As can be seen by the results of the analysis, I failed to confirm this finding with the data.

Table 4-7 Legislative Analysis: Outcome vs. Regulatory Regime Regulatory Regime 


\begin{tabular}{l|ccc|c}
\cline { 2 - 4 } Outcome & weak & intermed & strong & Total \\
\hline died/vetoed & 3 & 3 & 6 & 12 \\
enacted & 3 & 2 & 2 & 7 \\
\cline { 2 - 4 } & 6 & 5 & 8 & 19
\end{tabular}

Chi square (obtained) $=\quad 0.95$

Degrees of freedom $=\quad 2$

Alpha $=$

0.1

Chi square $($ critical $)=\quad 4.605$

I also conducted analyses of the data presented in Tables 4-1 and 4-2 in order to determine the relationship between the regulatory regime in each state and the regime of takings legislation that is exhibited. As explained in Chapter 3, the Spearman's rho technique of statistical analysis was used to examine these variables. The spreadsheets containing this analysis are provided in Appendix A.

\section{Regulatory Regime and Number of Bills Introduced}

In order to conduct the Spearman's rho analysis, the states were ranked by regulatory regime and the number of bills introduced. The analysis then compared the relationship between these two factors and returned a figure of 0.86 . Compared to a perfect correlation of 1.0, this figure indicates that there is in fact a strong positive relationship between the variables compared. Those states with the stronger regulatory regimes generally had the most takings bills introduced. This is consistent with one the hypotheses presented above. I expected to find that, as shown above, though states with strong regulatory regimes had fewer bills enacted, these states saw a higher number of bills introduced.

\section{Regulatory Regime and Strength of Bills}

For this measure the strength of the regulatory regime in each of the states was compared to the average strength of the bills introduced. Unlike the previous measure, the analysis indicated that there is a weak relationship between these two variables, returning 
a figure of 0.18 . This indicates that there is no significant statistical relationship between the strength of the regulatory regime and the strength of the legislation introduced in these states. However, based on the following analysis it appears that the strength of the bills is important.

\section{Regulatory Regime and Legislative Regime}

In a combination of the above two analyses I conducted a Spearman's rho analysis for regulatory regime and for the legislative regime presented in Table 4-6. Again, the spreadsheets are provided in Appendix A. For this analysis the correlation was very strong, at 0.89 . This indicates that the states with the strongest regulatory regimes generally had the strongest legislative regimes. While the strength of legislation alone did not show a statistically significant correlation to the regulatory regime, in combination with the number of bills introduced there is an increased level of correlation.

In order to test the hypothesis that the stronger bills enacted are in those states with weaker regulatory regimes I conducted a chi square analysis. Table 4-8 shows the data for the analysis. The results of this analysis shown below indicate that the regulatory regime in the states did have an impact on the strength of the bills enacted. Weak bills were enacted in states with both weak and strong regulatory regimes, while strong bills were enacted in the state with the intermediate level of regulation. I am hesitant to state that these results lend support to hypothesis however. Due to the lack information for several bills in the states it is impossible to determine the outcome or strength of these bills. Obtaining this data would be task in future research on this topic. 
Table 4-8 Legislative Analysis: Bill Type vs. Regulatory

Regime

\begin{tabular}{l|ccc|c}
\hline \multirow{2}{*}{ Enacted Bills } & \multicolumn{3}{|c|}{ Regulatory Regime } \\
\cline { 2 - 4 } & weak & intermed & strong & Tota \\
& & 0 & 2 & 5 \\
prelim/assess & 3 & 2 & 0 & 2 \\
\cline { 2 - 4 } entitlement & 0 & 2 & 2 & 7
\end{tabular}

Chi square (obtained) $=$ 7.00

Degrees of freedom= Alpha= Chi square $($ critical $)=$

2
0.1
4.605

\section{CONCLUSIONS}

The analyses indicate that there are some important correlations between the regulatory regimes and the legislative outcomes in the states. Beginning with a detailed examination of the regulatory regimes of the states, and then the examination of the takings legislation, I concluded this chapter by showing that the regulatory regime of the state does have an impact on the type and frequency of takings legislation that is introduced. Consistent with the hypothesis, the analyses determined that states with high levels of regulation also saw high numbers of takings bills introduced compared to states with weak regulation. The analyses failed to prove, however, that states with weak regulation are more likely to enact strong takings legislation. The analyses also failed to show a relationship between the number of bills enacted and the regulatory regime of the state. While the analyses did not show a strong statistical relationship between the regulatory regime and the strength of bills introduced as was expected. the combination of strength of bills and number of bills into a legislative regime for each state resulted in a finding of a strong positive correlation between the regulatory regime and legislative 
regime in the states. Those states with strong regulatory regimes also considered stronger takings bills. 


\section{Chapter 5}

\section{RHODE ISLAND: A CASE STUdy}

\section{INTRODUCTION}

This chapter takes a closer look at Wise Use in the State of Rhode Island and Providence Plantations. Even though Rhode Island is a small state, it has shown leadership in terms of planning and environmental regulation (Meck 1997). And even though Rhode Island is intensely developed (having the second highest population density in the country), there are some opponents to the State's efforts at regulation of development and protection of what remains of the natural environment. As was seen in the previous chapter, states with the strongest land use regulation also see the most activity in terms of number of takings bills introduced. Rhode Island is consistent with this observation. This chapter will examine the current status of regulation, takings legislation, and the Wise Use movement in Rhode Island.

\section{REGULATORY REGIME}

As discussed in Chapter 4, of the six states studied, Rhode Island is among those with the strongest planning and environmental regulatory regimes. 


\section{Planning Regulation}

Rhode Island is one of a minority of states with a comprehensive approach to growth management and planning at the statewide level. The Rhode Island program has been found to be one of the most effective programs in the United States (Meck 1997). Rhode Island is one of three states studied here that have such programs. The other two are Maine and Oregon. The impetus for creating the Rhode Island program seems to have been the development boom that the state experience in the mid-1980's (Meck 1997). During that time, developers and planners alike found that the existing planning and zoning statutes were inadequate to control development.

There are three essential pieces of state enabling legislation that, when combined, make up the state planning regime. First is the Comprehensive Planning and Land Use Regulation Act of 1988 (RIGL Section 45-22.2-2). This law requires all 39 cities and towns in Rhode Island to prepare comprehensive plans. Each plan must contain nine elements, including land use, housing, economic development, natural and cultural resources, services and facilities, open space and recreation, circulation, and implementation. Municipalities may also add additional elements. The plans must be submitted to state planning officials for approval. Plans are distributed to various state agencies that have an interest in the proposals and policies that are being considered. Communities must satisfy the concerns of each of these agencies, and be consistent with elements of the State Guide Plan. The State Planning Council, which is responsible for coordination of planning activities of agencies at the state level. produces the strategic plan of state goals and policies. Components of the strategic plan may become elements of the State Guide Plan which addresses land use issues (APA 1998). Once the local 
comprehensive plan is approved by the state, any state projects to take place in the community must conform to the plan.

The next piece of the puzzle is zoning enabling legislation. In 1991 the State Legislature passed a new zoning enabling act, applying to all communities (RIGL Section 45-24-2). This act effectively cleaned up many of the abuses that were prevalent in zoning administration (Meck 1997). It also allows for the use of innovative planning techniques. such as cluster development, transfer of development rights, and floating zones. Through the act, zoning procedures and definitions were made uniform statewide. Finally, and most importantly, the act requires that zoning be consistent with the locally adopted comprehensive plan. Once the plan is adopted, zoning must be brought into conformance.

The third and final piece of Rhode Island's planning regulatory framework is development regulation. In 1992 the State Legislature passed the Land Development and Subdivision Review Enabling Act. (RIGL Section 45-23-1). Again, these regulations apply to all 39 cities and towns in the state. The Planning Board in each community was given final approval authority for subdivision and land development projects. The Act established standard review procedures, including time limits for each stage of the review process. Subdivisions and development projects are classified as administrative, minor, or major projects depending on the size of the development. This classification determines the review process that must be followed.

\section{Environmental Regulation}

Virtually all environmental regulation in Rhode Island is administered at the state level. The Department of Environmental Management has the primary responsibility over regulations that impact the use of land. These include fresh water wetlands and individual 
sewage disposal system (ISDS) regulation. The Coastal Resources Management Council

(CRMC) regulates development in Rhode Island's coastal zone, including administration of coastal wetlands regulations.

As mentioned in the previous chapter, Rhode Island is ranked highly among the states in terms of environmental protection. Rhode Island regulates land uses in and adjacent to fresh water wetlands and coastal wetlands (RIGL Sec. 2-1-20). Rhode Island also has statutory protections for endangered species (RIGL Sec. 20-37-2). Rhode Island, however, is not a "mini-NEPA" state; that is, there is no requirement at the state level for assessment of a project's environmental impact. However, municipalities in the state have the authority to request that an impact statement be done for any major subdivision or land development project that must receive Planning Board approval.

Although I found that Rhode Island ranks well in terms of planning and environmental regulation in comparison to other states. James Lester categorized RI as a "regressive" state with low capacity and commitment to environmental protection (Lester 1990). In this paper Lester was addressing the impact of the decentralization of environmental protection from the federal government to state governments. He placed each state into one of four categories based on the capabilities and commitment of the state government to protect the environment: progressives, strugglers, delayers. and regressives. He stated that in the states categorized as regressive, decentralization "will likely be a disaster" (Lester 1990. 74). Consistent with Lester's skepticism, in just the last year Rhode Island has failed to satisfy EPA`s requirement for statewide auto emission inspection, putting federal highway funding in jeopardy (Providence Journal 1997). Also, EPA has expressed concern over the state's ability to satisfy the mandates of the Clean 
Water Act. Specifically, EPA expressed concern for staffing levels and technical capacity of the Rhode Island Department of Environmental Management (RIDEM) (Providence Journal 1997).

While Rhode Island ranks well in terms of its statutory framework for environmental protection, in terms of agency support, the State has shown a weak financial commitment to environmental protection. Rhode Island allocated just $1.23 \%$ of total State expenditures in 1986 to environmental protection, putting it in the middle of the pack, behind states like Mississippi, West Virginia, and Kentucky (Lester 1990). As will be discussed below, Rhode Island citizens have generally been supportive of environmental protection, generally supporting bond issues for environmental protection.

\section{TAKINGS LEGISLATION}

As was seen in Chapter 4, of the six states studied, Rhode Island had the most takings bills introduced in the state legislature. However, the last bill was introduced in January 1996, two years ago. The first bills recognized as having property-rights implications were introduced in 1992. These were not all-encompassing takings bills as were several of the bills discussed in the previous chapter. These bills only addressed wetland regulation by RIDEM. One provision would have required RIDEM to purchase property where a wetlands permit was denied (Bishop 1998). In 1993 and 1994 more omnibus takings bills were introduced. These bills were primarily takings assessment bills. They would have required the Attorney General to draft guidelines for state agencies to use when drafting regulations in order to identify the potential takings implications. The 1994 bill passed in the House but lost in the Senate. A similar bill saw the same fate in 1995 
(H.B. 5241)(Bishop 1998). In the 1993-4 legislative session HB 7698 was passed and adopted. This bill created a legislative study commission on property rights and rule making. This would be classified as a preliminary measure according to Emerson's typology discussed in Chapter 2. It established the commission, but it required no action on the part of government officials (Emerson 1996).

The last takings bill to be introduced in the Rhode Island Legislature was H.B. 7868 in 1996. As discussed in the bill summary presented in the previous chapter, this was also an assessment bill. It would have required the Attorney General to draft guidelines for state agencies to use to determine the takings implications of proposed regulations. This bill died in the House Judiciary Committee.

All of these bills were supported by members of Rhode Island Wise Use and other organizations, such as the Rhode Island Farm Bureau, and builders and Realtor associations (Bishop 1998). In fact, RI Wise Use was born as an association of interested parties around these issues.

\section{Perspective of a Legislative Analyst}

According to Ken Paine, State Senate Policy Analyst, there has been little legislative activity in the area of property rights and takings recently (Paine 1998). Mr. Paine indicated that while there is a constituency of those that support limits on regulation, this is a small and poorly organized group. It consists primarily of Brian Bishop of Rhode Island Wise Use, and farming interests in the state. Mr. Paine pointed out that farmers are a small constituency in this state. He cited this and the lack of large tracts of land as reasons for the lack of action on the issue of property rights issues when comparing Rhode Island to other states. 
Mr. Paine sees the issue of property rights as being less important in Rhode Island than other states. However, he did identify related issues that have received significant attention recently. First, the Rhode Island Department of Environmental Management (RIDEM), as will be discussed in some depth below, has been the target of legislative efforts to reform and reduce regulatory powers. Some legislators and RI Wise Use have charged that RIDEM regulators are overzealous and lack respect for the public. My research indicates that RIDEM reform is on the top of the agenda of RI Wise Use. Environmental regulation, particularly wetland regulation, has been cited most often in my communications with RI Wise Use as the major issue. Mr. Paine also cited coastal property ownership as a ripe property rights issue in Rhode Island. The combination of high property values, environmental regulation, and public access issues has made coastal areas prime ground for takings disputes.

Mr. Paine indicated that from his perspective, there is no real push for takings legislation to be introduced in Rhode Island in the near future. In addition to the lack of a substantial constituency in support of takings legislation, he feels that there has begun a resurgence of concern for the environment. He cited the recent conference on sustainable development held at the University of Rhode Island in April 1997, which attracted over 400 people. The issue of sustainable development has been getting an increasing amount of attention from several constituencies recently, including planners, preservationists, and business and government leaders. He sees this as a much stronger force in Rhode Island than the efforts to limit environmental and land use regulation. In short. Ken Paine sees property rights and takings legislation as a non-issue in Rhode Island now. In fact, even Brian Bishop of Rhode Island Wise Use admits that it is unlikely that any explicit 
property rights legislation will be passed in the near future. He believes that greatest potential for protecting property rights is through legislative oversight of RIDEM (Bishop 1998). This oversight has begun. and is discussed below.

\section{The Rhode Island Constitution}

As was seen in the descriptions of the bills presented in Chapter 4, many takings bills are based on the U.S. Constitution and the state constitution for the determination of what constitutes a taking. In the case of Rhode Island Bill 96-H 7868 the standard for taking was the $5^{\text {th }}$ and $14^{\text {th }}$ amendments of the U.S. Constitution. There is no reference to the Rhode Island Constitution. This may be of some significance rather than an unimportant omission. In some other states, including Kansas, state constitutional language regarding takings of private property mirrors the U.S. Constitution. In Rhode Island, however,

Article I, Section 16 of the Constitution of the State of Rhode Island and Providence Plantations reads as follows:

Compensation for taking of private property for public use: Regulation of fishery rights and shore privileges not public taking. Private property shall not be taken for public uses, without just compensation. The powers of the state and of its municipalities to regulate and control the use of land and waters in the furtherance of the presenation, regeneration, and restoration of the natural environment, and in furtherance of the protection of the rights of the people to enjoy and freely exercise the rights of fishery and the privileges of the shore, as those rights and duties are set forth in Section 17. shall he an exercise of the police powers of the state, shall be liberally construed. and shall not be deemed to be a public use of private properth. (emphasis added)

The rext identified in italics was added as a result of the Constitutional Convention of 1986. Put into simple terms, State and local environmental regulation cannot be found to be a taking of private property for public use without just compensation. This language seems to indicate that a bill that would classify environmental protection or land use regulations as "takings" would be doomed to fail a constitutional test in Rhode Island. It 
may be that the only type of bill that would be allowed to stand would be one that established a study commission, or a bill that required guidelines and assessment of proposed regulation for takings implications, such as 96- $\mathrm{H} 7868$. However, with the constitutional protections, it seems that a takings assessment on environmental and land use regulation would fail.

Incorporation of this language into the constitution did not go without some debate. As mentioned above, a Rhode Island Constitutional Convention was held in 1986. As might be expected there were several controversial issues addressed by the delegates. In the end. 14 questions were placed on the ballot for the citizens of the state to decide. Question 9 addressed the issues of access to the shore and environmental protection, and was worded as follows:

Shall rights of fishery and privileges of the shore be described and shall the powers of the state and local government to protect those rights and the environment be enlarged? Shall the regulation of land and waters for these purposes not be deemed a public use of private property?

The drive to amend the Rhode Island Constitution with such provisions was spearheaded by George L. Sisson, Jr., a member of Save The Bay, a local environmental watchdog organization (Providence Journal, 10/23/86, A 12). He was also Vice Chair of the Coastal Resources Management Council (CRMC), the state agency with jurisdiction over development issues in Rhode Island's coastal zone. At CRMC Sisson had seen what he believed to be a pattern of permits being issued out of the fear of being sued for a taking. This had been a real fear since the Rhode Island Supreme Court had ruled in favor of a property owner in a decision that required the Town of South Kingstown to compensate the property owner after refusing to grant a building permit for construction 
of a home on an environmentally sensitive barrier beach. This constitutional amendment was meant to address this situation (Providence Journal, 10/23/86, A12).

Both parts of the amendment involved implications for takings law. The first had the effect of ensuring public access to the shoreline, and took language directly from a 1941 Rhode Island Supreme Court decision to that effect. The second part was intended to bring environmental issues into consideration when judges look at property rights cases (Providence Journal, 10/23/86, A 12). In 1986 the amendments were known as the "Shore use" question. The hot issue at the time had to do with access to the shoreline. But perhaps the more far reaching issue was the protection of land use and environmental regulation from takings claims.

This conclusion was voiced in an editorial in the Providence Journal (October 31, 1986). The editor identified the primary issue as property rights vs. environmental protection. and found that "the nod goes in favor of the environment." The author recognized the implications of the amendment. While stating that the right to private property is a basic right guaranteed by both the U.S. and Rhode Island Constitutions, land use regulation has been upheld as constitutional and is necessary. The editorial referenced the RI Supreme Court's interpretation of the takings issue as discussed in the case above. and stated that regulation without the need for compensation is essential for maintaining the state"s "environmental heritage."

Opposition to the amendment was based on the grounds of private property rights. Individual shoreline property owners were concerned about their ability to restrict pubic use of what they perceived to be private property. The State Bar Association and the State Association of Realtors also opposed the amendment. The President of the Realtors 
Association at the time. Thomas E. Mulhearn, was quoted in the Providence Journal as stating that the provisions were an "infringement on property rights" and in violation of the "just compensation" clause of the U.S. Constitution. He felt that the amendment would be ruled invalid in the federal courts (Providence Journal, 10/23/86. A I2). The Bar Association and the builders felt that the provisions would require private property owners to bear the financial burden for providing a public good. This gets to the heart of the takings issue. and is the same claim made by Wise Use organizations.

As stated above, I find that the citizens of Rhode Island are generally supportive of environmental protection. In 1986, all of those running for statewide office, Democrats and Republicans alike, supported the amendment (Providence Journal 1 1/2/86, C2). This included the candidates for Governor. Bruce Sundlun, the Democratic candidate, stated that the amendment might infringe on the rights of property owners, but that it was needed in view of the rapid development of the state's coastline (Providence Journal 10/31/86, A 15). Question 9 was approved by the voters on November 4, 1986, 67.9\% to 32.0\%. This was the largest margin of approval of the 14 questions. It was passed in all 39 cities and towns in the state (Providence Journal 11/5/86, A1). In the same election, voters overwhelmingly approved several environmental bond issues totaling over $\$ 60$ million, another indication of Rhode Islanders' commitment to the environment.

While Rhode Island government may be lacking in its ability or willingness to make environmental protection a top priority as has been argued, it appears that legislative commitment is not lacking. Through the votes of legislators and the citizens one can see a high level of commitment to land use control and environmental protection. Rhode Island 
has some of the most progressive statewide planning and zoning legislation in the country, and citizen support for land use and environmental regulation is evident. However, a lack of funding and support from the executive branch has limited the effectiveness of the implementation of the commitment. Against this backdrop. a description of the efforts to refocus attention on the issue of property rights will follow.

\section{RHODE ISLAND WISE USE}

As discussed in Chapter 2, the Wise Use movement is a national phenomenon aimed at reducing government regulatory control over land use practices, particularly regulations for environmental protection. As might be expected in a state as small and as heavily developed as Rhode Island, the issues are of a different scale than those in western states. In the West, logging large expanses of old-growth forest and grazing of large tracts of rangeland are issues that have received national attention. In Rhode Island, the major issue is state environmental regulation, particularly wetlands regulations. In either case, however, the underlying argument is over property rights. What rights do property owners have? What are the limits of governmental power to regulate the use of land? As with the national movement. RI Wise Use argues that property owners have the right to do what they wish with their land. All government regulation infringes on this right.

\section{Organization}

Rhode Island Wise Use is a loose-knit group of people with an interest in reducing government regulation of land use practices. According to Brian Bishop, the leader of the group, most members have had problems of some kind with RIDEM, either violations or 
difficulty securing permits (Bishop 1998). In fact, Mr. Bishop himself has been cited for wetland violations. Through correspondence and discussion with Mr. Bishop. I have gained a good understanding of the philosophy of RI Wise Use. The underlying theme is that government regulation of any type is unnecessary and intrusive.

According to Bishop. RI Wise Use was first organized in 1992 in support of a takings bill that was introduced into the state legislature. Bishop used RIDEM records to find individuals that had been issued wetlands violations. He contacted these people, some of whom now form the nucleus of RI Wise Use (Bishop 1998). In the beginning, Bishop was not familiar with the national property rights movement. He was contacted by groups from other states, and then met with Ron Arnold, national Wise Use leader. Bishop stated that he was pleased to get involved with the national issues since takings legislation in Rhode Island had not seen much success. Bishop first named his new group Rhode Island Property Rights Advocacy Partnership (RIP RAP). After becoming familiar with agendas of other "wise use" groups he adopted the catch phrase, hence Rhode Island Wise Use. There are currently approximately 300 individuals on the RI Wise Use mailing list (Bishop 1998). There are no dues collected; however, the group does receive donations. Bishop stated that RI Wise Use has received and spent approximately $\$ 6,000$ over the past seven years.

Brian Bishop describes himself as a "Mr. Fix-it" and has a high-school education. He maintains apartment buildings in the Providence area. In the past he had done construction work. Bishop lives on a farm in rural Exeter, Rhode Island, approximately 20 miles south of Providence. Bishop stated that the major theme of his life has been to "question authority." He has rejected traditional educational institutions. and has 
conducted his "professional life without permits or vocational endorsements" (Bishop 1998). As discussed above, Bishop continues to fight for property rights protections, currently focusing on limiting the power of RIDEM.

\section{A RI Wise Use Meeting}

On December 7, 1997 a meeting of Rhode Island Wise Use was held at the home of the group`s leader, Brian Bishop. Such meetings are monthly events organized by Mr. Bishop as a way of bringing members of the group together to socialize and to discuss issues that are important to the members. Guest speakers are invited to address the group and to discuss issues. The December 7 meeting featured guest speaker Andrew McLeod, Director, Rhode Island Department of Environmental Management. Approximately 30 people with varied interests attended the meeting, including members of RI Wise Use, Farmers, state legislators, a representative of the Southern Rhode Island Conservation District, and students.

Mr. McLeod began by discussing his background, including his work in California Governor Pete Wilson's administration for the California Division of Forestry. Mr. McLeod was drafted in September 1997 by Rhode Island Governor Lincoln Almond to replace DEM Director Timothy Keeney, who resigned to pursue a career in the private sector. Through his young tenure at DEM Mr. McLeod has made an effort to reach out to various groups and individuals that have dealings with DEM. As will be discussed in the next section, DEM has been accused by some State legislators and RI Wise Use of being extreme and heavy-handed in its enforcement of State environmental protection regulations. The State Legislature has proposed changes to the agency and its procedures in order to address these problems. I believe that Mr. McLeod is working, through such 
public appearances, to improve the image of the agency as being out of touch with those parties in the state that it regulates.

Mr. McLeod also seems to be promoting a philosophy of environmental protection that differs somewhat from the traditional approach in Rhode Island. He spoke of the possibilities for economic development in conjunction with environmental protection. He also emphasized the need for government agencies to work in cooperation with property owners in the drafting and enforcement of regulations. One important change in philosophy that the Director is promoting is a "watershed" approach to environmental regulation. He stated that looking at single specific issues, such as wetlands or water pollution, without examining the larger context of issues leads to inflexibility. He used the examples of a watershed and an ecosystem as the level of detail that environmental protection should address.

Mr. McLeod also listed some of the specific initiatives that he will pursue during his tenure at DEM. These include maintaining the position of ombudsman in the Department to act as a go-between for the public and regulators. This is related to continuing the Information Office at DEM to assist applicants. There will also be an attempt to "streamline" the permitting procedures, including changes in the administration of individual sewage disposal system (ISDS) and wetlands regulations.

Following Mr. McLeod's introductory remarks the floor was opened to questions. A few members of the Stamp family attended the meeting. The Stamps are a farming family in Rhode Island with a well known history of being cited for wetland regulation violations. Over the past several years their story has been reported in the local press. They claim that their family"s farming operation, and farming in general in Rhode Island 
has been a victim of unfair regulations and overzealous regulators. They claim that some members of the family have been forced to leave the state in order to continue farming. In speaking to members of the family prior to the meeting I found that they have general negative feeling toward governmental regulation, with a particular animosity for planning. They expressed these opinions with a great deal of emotion. The Stamps' case is presented in more depth in the next section.

The Stamps expressed some strong opinions about property rights. They feel that regulations have taken land use decisions from property owners and given this power to government regulators far removed from the land. Mr. McLeod stated that since environmental regulation began in the late 1960's and early 70's the philosophy has been that of command and control. This is beginning to change, with the decentralization of government. Power is being returned to local governments. Mr. Stamp also responded to the idea of looking at issues with a watershed or ecosystem approach. He stated that there is no such thing as an ecosystem. It is just a fabricated idea not based in science. McLeod responded, saying that people should not place great importance on terminology. It is important for the players in these issues to find common ground in order to work together. Mr. Stamp did express some flexibility by stating that there should be a spirit of cooperation rather than regulation. Mr. McLeod agreed.

Other attendees expressed concerns similar to those of the Stamps. Responding to the Director's proposal that there needs to be partnerships between DEM and property owners, one person expressed concern with having a partnership with an organization that she doesn't trust. 
An important issue that was raised was the limited ability of the DEM Director to make drastic changes at DEM. Mr. McLeod expressed that he is one man in an organization of roughly 500 employees. He relies heavily on his top level managers to advise him on the various issues that the department must deal with. These people, in some cases, still hold to the old command and control mentality, and the Director has little power over them. This concern was echoed by some of those in attendance. Some stated that it is the career "bureaucrats" that are the main problem. As will be discussed below, this situation may change with the reorganization that is proposed in the State Legislature.

Representatives of the Rhode Island Farm Bureau, also in attendance, expressed concern for the impact environmental regulation is having on the agricultural industry in the State. The Farm Bureau is an organization of approximately 650 Rhode Island farmers, many of whom claim that RIDEM has gone too far in its regulation of wetlands (Providence Journal 6/17/96, B1). The issue of the decreased profitability of farming was also raised. They argued that more should be done to assist farmers, rather than to drive them out of business.

There was also discussion of DEM rule-making procedures. Some participants felt that there should be an economic impact statement done whenever new regulations are proposed. There was also a concern that even when there is public input into the rule making process. concerns of the public are not taken seriously.

Throughout the question and comment period Mr. McLeod made great efforts to express his desire to make needed changes to the agency. Many attendees appeared to 
support the Director's comments. However, some seemed impatient with the prospect of slow change. They would rather see the total elimination of regulation immediately.

I was interested in the experiences that participants have had with DEM and other government agencies. It appeared that several of those present had had a negative experience with regulations. This includes the Stamp family, and others who had dealings with the RIDEM Division of Freshwater Wetlands. Emotions were running high on this issue. DEM biologists were even referred to as liars. It would seem to me that such experiences with regulation is a tie that binds members of RI Wise Use. There is also the deeper philosophy of environmental and land use regulation as an invasion of property rights. This is most clearly articulated by Brian Bishop, as discussed above.

Another item that is relevant to the issue that is addressed in this research is the obvious importance of the RI Wise Use group to government officials and politicians. The simple fact that the DEM Director was willing to spend a Sunday afternoon talking to a relatively small group of constituents is testament to their importance. It says that the current administration of Governor Lincoln Almond is making a serious attempt to improve the perception that people have of government. The increased prevalence of property rights disputes nationally, as well as locally, may also be a factor in the increased interest by government officials and politicians.

\section{THE LIGHTNING ROD: RI DEM}

The Rhode Island Department of Environmental Management is the State agency responsible for the administration of environmental protection throughout the State. The new Director of RIDEM is Andrew McLeod, who oversees a staff of approximately 570. 
and an annual budget of approximately $\$ 72$ million. Currently, the RIDEM Director is appointed by the Governor and confirmed by the State Senate. Other high level managerial posts in the agency are classified positions. As mentioned above, Mr. McLeod sees this as a situation that limits the Director's ability to influence the operation and direction of the agency. RIDEM has several divisions, including: natural resources; air. solid waste, and hazardous materials; water quality management: strategic planning; criminal investigations; and legal services. The responsibilities of the RIDEM include the protection, preservation, and management of the State's natural resources, including 14,000 acres of state parks and management areas. The department is responsible for “preserving and enhancing the State's many historical, coastal, and recreational resources; maintains and protects land and water areas for wildlife preservation and public recreation; performs regulatory functions affecting water resources, water supplies, and wetlands; oversees air, solid waste and hazardous material control programs" (RIDEM 1998).

As mentioned above, RIDEM has been the focus of recent efforts to limit regulatory power. Of particular concern has been wetland regulation. In 1995-1997 there was a series of stake-holder meetings to revise the state's wetland and ISDS regulations. A committee, established by the Governor, presented recommendations to the Legislature in 1997. Also. legislative hearings held on these issues raised the concern that RIDEM had gone beyond legislative intent in its rule-making, leading to a perception of an abuse of power. Brian Bishop of RI Wise Use and Lee Gardner of the RI Farm Bureau have been on the frontline of the issue. Gardner argued that landowners should be compensated for loss of land value due to regulation. He was quoted in the Providence Journal as stating. 
"There are uses that are better than providing places where mosquitoes bite and rabid raccoons are raised." This indicates the deep differences in opinion that exist among the various interested parties regarding the value and importance of wetlands. It also illustrates the strong feelings that exist over property rights. These comments echo the feelings of Brian Bishop: There should be no land use regulations of any kind. Wise Use activists contend that any government restriction of land use without compensation violates the U.S. Constitution.

A few high profile cases, including those involving the Williamses, and the Stamps were reported and discussed through the course of the hearings. (The Williamses, the Stamps, and Lee Gardner of the RI Farm Bureau were all at the RI Wise Use meeting that I attended). Their cases might be called horror stories. The Williamses reportedly purchased property in order to build a home in Little Compton, RI. They were apparently given approval to install an ISDS by RIDEM regulators. A subsequent inspection by RIDEM wetland biologists found both the ISDS and the foundation for the house violated wetland regulations. The Williamses claim to have spent over $\$ 300.000$ fighting RIDEM, trying to get approval for construction of a new home (Providence Journal 3-13-97. B 1). At the RI Wise Use meeting Mrs. Williams confronted the RIDEM Director on this issue. Mr. McLeod appeared to be well aware of the situation and stated that RIDEM would continue to do all it could within its power to address the concerns of Mrs. Williams. The Stamps have become the "poster family" for all those in Rhode Island that are opposed to land use and environmental regulation. They claim that due to regulation in Rhode Island, members of the family have had to relocate in order to continue farming. A 
member of the Stamp family who has begun farming in New York was at the RI Wise Use meeting.

Although their confrontation has been primarily with the U.S. Army Corps of Engineers. they have also had their differences with state and local officials through the years. The current issue is not so much a question of farming as it is a development issue. Bill Stamp has been trying to develop an industrial park on his 100 -acre farm in suburban western Cranston, RI for several years. In 1978 the farm, located near the then new Interstate 295, was rezoned for industrial use. Property taxes on the farm reportedly went from $\$ 4,000$ to $\$ 72,000$ per year. The Stamps and other property owners successfully opposed the assessment in court. This was the first round in the battle over this property.

In later years, when Stamp proposed an industrial park on the land, he received both City and RIDEM approval for the development. As is routine, the application was forwarded to the U.S. Army Corps of Engineers. Not routine was the Corps' decision to overrule RIDEM`s wetland determination. From that point the Stamps and the Corps have been in a prolonged battle over the amount of wetlands on the property. When RIDEM tried to revoke its wetland approval, claiming that it had expired, a Rhode Island Superior Court judge sided with the Stamps, expressing much sympathy over their plight (Lord 1996). From zoning to wetlands regulation, the Stamps have been on the frontline of property rights issues in Rhode Island for years. This helps to explain the anger and frustration that was expressed to me and to the RIDEM Director at the RI Wise Use meeting.

With this foundation of high profile accusations of RIDEM excesses, in 1997 a legislative commission consisting of members of both houses of the General Assembly 
was formed: the Kennedy Commission. A series of public hearings were held, and many were aired on local cable television. This issue caught the attention of many in the state, including Brian Bishop of RI Wise Use. He stated that his group wasn't tracking legislation for the possibility of a takings bill "because the battleground had moved to this forum" (Bishop 1998).

The Kennedy Commission was a sounding board for all those with a concern about the way RIDEM has gone about the business of regulating for environmental protection. Commission members reportedly found the testimony to be an indication of RIDEM's incompetence and indifference to the public (Providence Journal 5/6/97, Al). Among others, Brian Bishop and representatives of the Realtors and builders associations gave testimony at the hearings. Some officials at RIDEM reacted by calling the hearings a "witch hunt." It seems that public hearings were probably needed in order for state legislators and RIDEM to respond to, and to address the legitimate concerns of many in the state. Recommendations from the commission, which include changes in the management structure of RIDEM, are to be forwarded to the legislature for consideration.

\section{CONCLUSION}

The State of Rhode Island is a microcosm of the property rights debate. Many of the issues being debated in other states and at the national level have been addressed by the players in the state. Rhode Island. however, has not experienced the intensity of the property rights and Wise Use movements that other parts of the country have seen. The most active area of contention in recent times has been dealing with environmental regulation, and the powers of RIDEM. 
As described above. Rhode Island appears to be split when it comes to commitment to environmental protection. While the citizens of Rhode Island have shown support for environmental bond issues, the State Legislatures and Governors over the years have exhibited less commitment. This could be an explanation for the limited support for RI Wise Use. With limited governmental commitment, and high popular support for environment protection, RI Wise Use has limited targets for its efforts, and a limited base of support. It may be that once the concerned public recognizes that any needed change in the regulatory approach of RIDEM is moving forward, calls for takings legislation will diminish. The hot-button issue will have been resolved.

Furthermore, this research has not identified any significant opposition to existing planning and land use regulations in the state. In fact, it appears that there may be some momentum in the direction of increased efforts to limit development sprawl into rural communities. It will be interesting to see if Rhode Island stays on the track of progressive planning and land use policy. 


\section{Chapter 6}

\section{Conclusions}

This research project presents the issue of property rights and takings. It discussed the previous research done in this area, and the legal foundation of the takings issue, and introduced the current efforts to strengthen property rights in this country. It presented a comprehensive examination of the Wise Use movement on the national and state level and reviewed the tactics of the various groups that make-up the movement. concentrating particularly on takings legislation in the states. The research studied takings legislation and the regulatory regime of six states in order to determine the relationship between the type and strength of environmental and planning regulation and the prevalence of takings legislation. A case study of the State of Rhode Island and Providence Plantations was conducted in order to gain an understanding of the players, and to examine the dynamics of the property rights debate. Following is a summary of my conclusions and suggestions for future research.

\section{WISE USE}

Through the course of this project I have identified "Wise Use" as the umbrella term that applies to any number of organizations that have an interest in reducing the impact of environmental and land use regulation. There is no national organization; however, there 
is a national leader and spokesperson for the movement. Ron Arnold. While the bulk of the action takes place at the local and state level, Ron Arnold and others have also supported efforts to enacted federal legislation to achieve their goals.

There are as many as 250 groups nationwide that would fall under the umbrella of Wise Use. While their issues vary to some extent, the primary focus of all these groups is to secure individual property rights they feel are threatened by government regulation and federal natural resource policies. As discussed in Chapter 2, the groups have strong ties to the extractive industries through membership and financial support. Rhode Island Wise Use membership consists of farmers as well as individuals that have been cited or restricted from conducting some land use activities regulated by environmental and land use regulations. Chapter 5 provided a discussion of the issues that are the focus of attention of RI Wise Use. State environmental regulation, particularly wetland regulation seems to be the tie that binds the members of RI Wise Use.

Previous research on Wise Use, together with my research, identified the foundation of the property rights debate to be constitutional takings law. Most of the information I have gathered, including the policy statements of various Wise Use organizations, ground the discussion and arguments on the takings clause of the $5^{\text {th }}$ and $14^{\text {th }}$ amendments to the U.S. Constitution. Chapter 2 provided a comprehensive discussion of the history and current status of takings law in the United States. In general, environmental and land use regulation has been held as a constitutional exercise of the government's police powers to protect the health, safety, and welfare of the populace. Wise Use Groups and other individuals involved in the debate contend that regulation of land use infringes on constitutional protections. 
In the planning context, takings law is extremely important. Planning, especially zoning, subdivision regulation, and other implementing regulatory tools, is allowed to continue only as a result of the current legal interpretation of takings law. Gaining an understanding of the arguments against such regulation is vital to the effort to maintain planning and environmental protection. Planners are uniquely qualified to understand these issues, and to educate the general public of the importance of prudent land use regulation.

\section{TAKINGS LEGISLATION AND THE STATES}

Chapter 4 provided the discussion of the regulatory regimes and the history of takings legislation in six states (Kansas, Maine, Mississippi, Montana, Oregon, and Rhode Island). As discussed above, the Wise Use movement is active at the state level. A primary goal of these organizations is to limit government regulatory power. This project looked specifically at the tactic of introducing legislation in the states that would have the effect of limiting this power. Chapter 2 provided an explanation of the various types of takings legislation that have been introduced in the states.

Chapter 4 presented several analyses of regulatory regime, takings legislation, and the correlation between these variables. The analysis of regulatory regimes revealed that there are many differences among the states in terms of how they provide environmental protection and regulate land use. The analysis revealed that Rhode Island, Maine and Oregon had strong regulatory regimes. while Kansas and Montana had weak regimes. Mississippi was intermediate. This was not at all surprising to me based on my prior knowledge and information gather during the research phase of this project. Maine and 
Oregon are generally recognized as leaders in environmental protection. In states such as Kansas and Montana which rely heavily on agriculture and other extractive industries I expected to see less emphasis on environmental protection and land use regulation.

The correlation between state regulatory regime and number of takings bills introduced the states was strong. The states with the strongest regulation saw the highest number of bills introduced. This indicates that the existence of regulations that are thought to impact property rights has the effect of inducing property rights activists and Wise Use organizations to influence legislators to introduce takings legislation.

Consistent with the hypothesis presented in Chapter 1 , the research found that the states with the highest level of regulation also had the highest number of bills introduced. The analysis. however, failed to confirm a statistically significant relationship between the number or strength of takings bills enacted and the regulatory regime of the state. Based on this information, it can be concluded that while high numbers of bills are introduced in states with strong regulation, there is no indication that bills are more likely to be enacted. The analysis of the outcome of legislation based on strength, found that weak bills are more likely than strong bills to be enacted.

These analyses reveal that even if high numbers of bills and strong bills are introduced in the legislature of these states, "cooler heads" have generally prevailed. When bills have been enacted, they have usually been the type that establish study commissions or that require state agencies to consider the takings implications of regulations. These types of bills do not directly impact the power to regulate land use. and therefore are not a direct threat to necessary and prudent planning and environmental regulation. Concern arises when we consider the forces behind the bills. Those who have 
promoted their passage are not satisfied with the enactment of these weak measures. As was found through the research, the goal of many in the Wise Use movement is to eliminate all land use and environmental regulation. Planners and others who understand the value of such regulation must remain active in the debate to avoid any further erosion of the government's power to protect public health, safety, and welfare.

\section{IMPLICATIONS FOR RHODE ISLAND}

This research reveals that the State of Rhode Island had the highest number of bills introduced of the six states studied. Rhode Island also had one of the strongest regulatory regimes of the states. Rhode Island is recognized as a national leader in statewide comprehensive planning. All of these factors are tied together. This research has led to the conclusion that there have been many takings bills introduced in Rhode Island precisely because of the progressive regulatory regime. This is supported not only by the data from other states as discussed above, but also through discussions with the players in the debate in Rhode Island.

As discussed in Chapter 5, the impetus behind the organization of RI Wise Use was primarily opposition to state wetland regulation by those that had been cited for violations or denied permits. Even though Brian Bishop and RI Wise Use now profess support for the cause of property rights in general, and are allied with other Wise Use groups nationwide. the research revealed that the core issue in Rhode Island is still wetland and other RIDEM regulations. Mr. Bishop acknowledged that his attention had shifted somewhat from takings legislation to the effort to restructure RIDEM. Based on this information. it can be concluded and predicted that once the issue of regulatory 
misconduct by RIDEM is fully addressed, and if the horror stories go away. RI Wise Use will lose much of its already limited support. As stated by Mr. Paine, the RI Senate Legislative Analyst, there seems to be much more support in Rhode Island for much needed statewide planning aimed at limiting the impact of development sprawl.

The research revealed a strong Wise Use effort in other parts of the nation. In fact. in some states takings legislation has begun to impact the powers of government to control land use. However, as discussed in Chapter 5, Rhode Islanders are generally supportive of environmental regulation and land use planning. Even Brian Bishop acknowledged that the prospects for any takings legislation in the near future are dim. Rhode Island planners should. however, stay ahead of the curve on this issue. The research indicates that there is a potential for the erosion of regulatory power, as has happened in other states. Planners must remain cognizant of the arguments on both sides of the issue in order to respond to future Wise Use initiatives. Planners must also recognize the implications of regulation, and its impact on property rights. In some cases, Wise Use groups have identified decided excesses of regulatory power. Planners and regulators should not disregard such claims, but should investigate and correct these problems. This is necessary to help maintain the legitimacy of the planning profession.

\section{LIMITATIONS/FUTURE RESEARCH}

As with any research project, not all the issues could be addressed here. It is hoped that this work will inspire further research into the Wise Use movement. This research was fairly limited in scope. It provides cursory examination of only six states, with indepth study of one state. Future research should expand on this by conducting in-depth 
research of more states. Of particular interest would be an examination of states where there is strong Wise Use activity, such as Oregon and Nevada. Based on this research it is suggested that an examination of those states which rely heavily on the extractive industries, including agriculture, timber, and mining be conducted. A comparison of the organization and political activity of Wise Use groups between the states could yield valuable information.

Other limitations of this research result from reliance on sources of data that were less than complete. Of particular concern is the limited data on takings legislation in the states. Future research should establish a complete database of state takings legislation nationwide, including the text and outcome of all bills introduced. The fragmentary database limited the ability to draw conclusions based on the types of legislation considered in the states.

Further research might also include a more complete inventory of Wise Use organizations nationwide. There is some debate over the true number and membership of these organizations. There is also debate over where the bulk of the financial and organizational support for the organizations is coming from. Wise Use claims that support is primarily grassroots; some environmental groups contend that this support comes form the extractive industries. Further research could settle this debate. 


\section{REFERENCES}

American Planning Association. 1997. "APA's Position on 'Takings"“ avilable on the internet as of September 5, 1997 at http://www.planning.org

American Planning Association. 1998. "Statutory Summary for the State of Rhode Island" available on the internet as of January 8, 1998 at http://www.planning.org

American Resources Information Network (ARIN). 1996. avilable on the internet as of March 10, 1998 at http://www.igc.apc.org/arin/

Bishop, Brian, RI Wise Use. 1998. Personal communication in response to my inquiries via E-mail. received January 10.

Center for the Defense of Free Enterprise. 1997. "Wise Use: What Do We Believe?" Available on the Internet as of 6/9/97 (http://www.eskimo.com/ rarnold/wiseuse.html.)

Citizens for a Sound Economy (CSE). 1997. "About CSE" available on the Internet as of 6/9/97 (http://www.cse.org/osay.html/.)

Clearinghouse on Environmental Advocacy and Research (CLEAR). 1996. A Clear Vien: "Twenty-five Point Agenda of the Wise Use Movement". available on the internet as of 9/4/96 (http://www.ewg.org/pub/home/Clear/Agenda.html.)

Echeverria, John and Raymond Booth Eby, eds.. 1995. Let the People Judge: Wise Use and the Property Rights Movement. Washington D.C.: Island Press.

Emerson. Kirk. 1996. "State Property Rights Legislation: A Policy Development Perspective" Presented at the Joint International Congress of the Association of Collegiate Schools of Planning and the Association of European Schools of Planning.

Gallagher, Mary Lou. 1996. "Wise Use or Wise Marketing?" Planning. 62.1: 4-9. 
Horbert, Charles, Permitting Supervisor, Wetland section. R.I. Department of Environmental Management. 1997. Interview by author. 14 September, South Kingstown. R.I.

Jacobs, Harvey M. 1996. "Whose Rights, Whose Regulations? Land Theory, Land Policy, and the Ambiguous Future of the New Private Property Rights Movement in the U.S." Environmental Planning Quarterly 13, 3: 3-8.

Kayden, Jerold S. 1996b "Private Property Rights, Government Regulation, and the Constitution: Searching for Balance" in H. Diamond \& P. Noonan, Land Use in America. Washington, D.C.: Island Press.

Lavelle, Marianne. 1995. "The Property Rights Revolt" in Let the People Judge: Wise Use and the Private Property Rights Movement John Echeverria and Raymond Booth Eby, eds. Washington D.C.: Island Press.

Lester, J.P. 1990. "A New Federalism? Environmental Policy in the States." in Environmental Policy in the 1990's. N.G. Vig and M.E. Kraft, eds. Washington: Congressional Quarterly Press.

Lewis, Thomas A. 1995. "Cloaked in a Wise Disguise" in Let the People Judge: Wise Use and the Private Property Rights Movement eds. John Echeverria and Raymond Booth Eby. Washington D.C.: Island Press.

Meck, Stuart. 1997. "Rhode Island Gets it Right." Planning 63, 11: 10-15.

Paine, Kenneth, Rhode Island State Senate Policy Analyst. 1998. Personal communication via telephone. January 9, 1998.

Pendall, Rolf, Ronald M. Wolanski \& Doug McGovern. 1997. "Property Rights and Property Culture: State property-rights bills and the districts whose legislators support them." paper presented at "Planning in the Americas," 39th annual conference of the Association of Collegiate Schools of Planning, Fort Lauderdale, Florida, 6 November.

Pertman. Adam. 1994. "Wise use foot soldiers on the march" Boston Globe. October 3, 1994: 25.

Ramos. Tarso. 1995. "Wise Use in the West" in Let the People Judge: Wise Use and the Private Property Rights Movement John Echeverria and Raymond Booth Eby. eds. Washington D.C.: Island Press. 
Riebsame. William E. and Robert G. Woodmansee. 1995. "Mapping Common Ground on Public Rangelands" in Let the People Judge: Wise Use and the Private Property Rights Movement John Echeverria and Raymond Booth Eby, eds. Washington D.C.: Island Press.

Strong, Ann Louise, Daniel R. Mandelker \& Eric Damian Kelly. 1996. "Property Rights and Takings" Journal of the American Planning Association 62, 1:5-16.

Thomas, David A. 1996. "The Illusory Restraints and Empty Promises of New Property Protection Laws" The Urban Lawyer 28, 2: 223-261.

Watkins, T.H. 1995. "Wise Use" in Let the People Judge: Wise Use and the Private Property Rights Movement John Echeverria and Raymond Booth Eby, eds. Washington D.C.: Island Press.

Williams, Florence. 1995. "Sagebrush Rebellion II" in Let the People Judge: Wise Use and the Private Property Rights Movement . John Echeverria and Raymond Booth Eby, eds. Washington D.C.: Island Press. 
APPEndix A

Statistical Calculations 


\section{Chi Square Analyses}

Table 4-3 Legislative Summary

\begin{tabular}{l|llr|r} 
Outcome & prelim & \multicolumn{3}{c}{ Bill Type } \\
assess & entitle & \\
\hline died & 0 & 2 & 8 & 10 \\
vetoed & 0 & 1 & 1 & 2 \\
enacted & 2 & 3 & 2 & 7 \\
\cline { 2 - 5 } & 2 & 6 & 11 & 19
\end{tabular}

$f e=$

\begin{tabular}{lll}
1.0526316 fo $=$ & 0 & 1.052632 \\
0.2105263 & 0 & 0.210526 \\
0.7368421 & 2 & 2.165414 \\
3.1578947 & 2 & 0.424561 \\
0.6315789 & 1 & 0.214912 \\
2.2105263 & 3 & 0.281955 \\
5.7894737 & 8 & 0.844019 \\
1.1578947 & 1 & 0.021531 \\
4.0526316 & 2 & 1.039645 \\
\hline
\end{tabular}

Chi square (obtained) $=\mathbf{6 . 2 5 5 1 9 5}$

Degrees of freedom $=\quad 4$

Alpha $=\quad 0.1$

Chi square $($ critical $)=\quad 7.779$

The obtained chi square is not within the critical region and is therefor the frequencies are not significantly different from what be expected in a random distribution.

Table 4-4 Legislative Analysis

\begin{tabular}{l|ccc|c}
\multirow{2}{*}{ Outcome } & \multicolumn{3}{c}{ Bill Type } \\
\cline { 2 - 4 } died/vetoed & preliminary & assessment & entitlement & Total \\
enacted & 0 & 3 & 9 & 12 \\
& 2 & 3 & 2 & 7 \\
\cline { 2 - 4 } & 2 & 6 & 11 & 19
\end{tabular}

$\mathrm{fe}=\left(\begin{array}{lll}1.2631579 \text { fo }= & 0 & 1.263158 \\ 0.7368421 & 2 & 2.165414 \\ 3.7894737 & 3 & 0.164474 \\ 2.2105263 & 3 & 0.281955 \\ 6.9473684 & 9 & 0.606459 \\ 4.0526316 & 2 & 1.039645 \\ \hline\end{array}\right.$

Chi square (obtained) $=\quad \mathbf{5 . 5 2 1}$

Degrees of freedom $=\quad 2$

Alpha $=\quad 0.1$

Chi square $($ critical $)=\quad 4.605$ 
Table 4-5 Legislative Analysis

\begin{tabular}{l|cc|c}
\multirow{2}{*}{ Outcome } & \multicolumn{3}{|c}{ Bill Type } \\
\cline { 2 - 3 } died/vetoed & prelim/asses & entitlement & Total \\
enacted & 3 & 9 & 12 \\
& 5 & 2 & 7 \\
\hline 8 & 11 & 19
\end{tabular}

$f e=$

$$
\begin{aligned}
& 5.0526316 \text { fo }= \\
& 2.9473684 \\
& 6.9473684 \\
& 4.0526316
\end{aligned}
$$$$
3 \quad 0.833882
$$$$
5 \quad 1.429511
$$$$
9 \quad 0.606459
$$

Chi square (obtained $)=$

3.909

Degrees of freedom=

Alpha=

Chi square $($ critical $)=$

2.706

\section{Table 4-7 Legislative Analysis}

\begin{tabular}{l|ccc|c}
\multirow{2}{*}{ Outcome } & \multicolumn{3}{c}{ Regulatory Regime } & \multirow{2}{*}{ Total } \\
\cline { 2 - 4 } died/vetoed & weak & intermed & strong & 12 \\
enacted & 3 & 3 & 6 & 7 \\
\cline { 2 - 4 } & 3 & 2 & 2 & 19
\end{tabular}

$f e=$

$$
\begin{aligned}
& 3.7894737 \text { fo }= \\
& 2.2105263 \\
& 3.1578947 \\
& 1.8421053 \\
& 5.0526316 \\
& 2.9473684
\end{aligned}
$$

\begin{tabular}{lr}
3 & 0.164474 \\
3 & 0.281955 \\
3 & 0.007895 \\
2 & 0.013534 \\
6 & 0.177632 \\
2 & 0.304511 \\
\hline & 0.95
\end{tabular}

Chi square $($ obtained $)=$

Degrees of freedom=

0.95

Alpha $=$

Chi square $($ critical $)=$

4.605

Table 4-8 Legislative Analysis

\begin{tabular}{l|ccc|c}
\multirow{2}{*}{ Enacted Bilis } & \multicolumn{3}{c}{ Regulatory Regime } \\
\cline { 2 - 4 } & weak & intermed & strong & Total \\
prelim/asses & 3 & 0 & 2 & 5 \\
entitlement & 0 & 2 & 0 & 2 \\
\cline { 2 - 4 } & 3 & 2 & 2 & 7
\end{tabular}

$\mathrm{fe}=$

$$
\begin{aligned}
& 2.1428571 \text { fo }= \\
& 0.8571429 \\
& 1.4285714 \\
& 0.5714286 \\
& 1.4285714 \\
& 0.5714286
\end{aligned}
$$

3

0.342857

0

0.857143

0

1.428571

2

3.571429

2

0.228571

0

0.571429

Chi square $($ obtained $)=$

7.00 
Degrees of freedom=

Alpha $=$

Chi square $($ critical $)=$
2

0.1

4.605

Spearman's rho Analyses

\begin{tabular}{lcccrrrr} 
& $\begin{array}{c}\text { Regulatory } \\
\text { Score }\end{array}$ & Rank & $\begin{array}{c}\text { Number } \\
\text { of Bills (1) Rank }\end{array}$ & D & \multicolumn{1}{c}{$\mathrm{D}^{2}$} \\
\hline Kansas & 5 & 5.5 & 2 & 6 & -0.5 & 0.25 \\
Maine & 11 & 2.5 & 5 & 3.5 & -1 & 1 \\
Mississipp & 8 & 4 & 5 & 3.5 & 0.5 & 0.25 \\
Montana & 5 & 5.5 & 4 & 5 & 0.5 & 0.25 \\
Oregon & 13 & 1 & 9 & 2 & -1 & 1 \\
Rhode Isla & 11 & 2.5 & 10 & 1 & 1.5 & 2.25 \\
\cline { 4 - 7 } & & & & & & 0 & 5
\end{tabular}

$r_{\mathrm{s}}=1-\left(6^{*} \operatorname{sumD}^{2} /\left(\mathrm{N}\left(\mathrm{N}^{2}-1\right)\right)\right)$

$r_{s}=1-\left(6^{*} 5 /(6(36-1))\right)$

$r_{s}=\quad 0.8571429$

\begin{tabular}{l|cc|cccrr} 
& $\begin{array}{c}\text { Regulatory } \\
\text { Score }\end{array}$ & Rank & $\begin{array}{c}\text { Average } \\
\text { strength } \\
\text { of bills }\end{array}$ & Rank & & D & \multicolumn{1}{c}{$D^{2}$} \\
\hline Kansas & 5 & 4.5 & 4 & 3 & 1.5 & 2.25 \\
Maine & 11 & 2 & 3.3 & 5 & -3 & 9 \\
Mississipp & 8 & 3 & 5.4 & 1 & 2 & 4 \\
Montana & 5 & 4.5 & 3.8 & 4 & 0.5 & 0.25 \\
Oregon & 13 & 1 & 5.3 & 2 & -1 & 1 \\
& & & & & & 0 & 16.5
\end{tabular}

$r_{s}=1-\left(6^{*} s_{m D^{2}} /\left(N\left(N^{2}-1\right)\right)\right)$

$r_{\mathrm{s}}=1-\left(6^{*} 5 /(5(25-1))\right.$

$r_{s}=\quad 0.175$

\begin{tabular}{lcccccrr} 
& $\begin{array}{c}\text { Regulatory } \\
\text { Score }\end{array}$ & Rank & $\begin{array}{c}\text { Legislativ } \\
\text { e Score }\end{array}$ & Rank & \multicolumn{2}{c}{ D } & \multicolumn{1}{c}{$D^{2}$} \\
\hline Kansas & 5 & 5.5 & 6 & 6 & -0.5 & 0.25 \\
Maine & 11 & 2.5 & 8.3 & 4 & -1.5 & 2.25 \\
Mississipp & 8 & 4 & 10.4 & 3 & 1 & 1 \\
Montana & 5 & 5.5 & 7.8 & 5 & 0.5 & 0.25 \\
Oregon & 13 & 1 & 14.3 & 1 & 0 & 0 \\
Rhode Isla & 11 & 2.5 & 14 & 2 & 0.5 & 0.25 \\
& & & & & & 0 & 4
\end{tabular}

$r_{s}=1-\left(6^{*} \operatorname{sumD}^{2} /\left(N\left(N^{2}-1\right)\right)\right)$

$r_{s}=1-\left(6^{*} 5 /(6(36-1))\right)$

$r_{s}=\quad 0.8857143$ 
APPENDIX B

ADDITIONAL READINGS 


\section{APPENDIX B}

\section{ADDITIONAL READINGS}

Babbitt, Bruce. 1994. "Endangered Species and 'Takings': a call for innovation" Envirommental Law 24, 2: 355-67.

Becker, Lawrence C. 1977. Property Rights: Philosophic Foundations. London, Boston: Routledge.

Brauneis, Robert. 1996. "The Foundation of Our 'Regulatory Takings' Jurisprudence: The Myth and Meaning of Justice Holmes's Opinion in Pennsylvania Coal Co. v. Mahon" The Yale Law Journal 106, 3: 613-701.

Carroll, Matthew S. 1995. Community and the Northwestern Logger: Continuities and Changes in the Era of the Spotted Owl. Westriew.

Cawley, R. McGreggor. 1993. Federal Land, Western Anger: The Sagebrush Rebellion and Environmental Politics. Lawrence, Kansas: University Press of Kansas.

Coyle, Dennis J. 1993. Property Rights and the Constitution: shaping societ through land use regulation. Albany: SUNY.

De Grove, John M. 1984. Land, Growth \& Politics. Washington: Planners Press, APA.

De Grove, John M. 1992. The New Frontier for Land Policy: Planning and Growth Management in the States. Cambridge, MA: Lincoln Institute of Land Policy.

Epstein. R.A. 1985. Takings, Private Property and the Power of Eminent Domain. Cambridge, MA: Harvard University Press.

Freilich, R.H. and R. Doyle. 1994. "Takings Legislation: Misguided and Dangerous." Land Use Law' and Zoning Digest. 47, 10: 3-6.

Hanna, S. and M. Munasinghe, eds. 1995. Property Rights and the Enviromment. Washington: Beijer International Institute of Ecological Economics. 
Helvarg, David. 1995. "Red Herrings of the Wise Use Movement" The Progressive 59, $11: 18$.

Helvarg, David. 1994. The War Against the Greens. San Francisco: Sierra Club Books.

Kayden, Jerold S. 1996a. "Private Property Rights, Government Regulation. and the Constitution: Searching for Balance" in Land Use in America eds. H. Diamond and P. Noonan. Island Press: Washington D.C.

Kriz, Margaret. 1996. "The center folds: A firestorm of opposition from environmental groups on one side and property rights advocates on the other..." Nature Journal 28: 1469-72.

Lacey, Michael J. ed. 1991. Government and Environmental Politics: Essays on Historical Developments Since World War II. Washington, D.C.: Woodrow Wilson Center Press.

Lester, James P.. ed. 1989. Environmental Politics and Policy: Theories and Evidence. Durham, NC: Duke University Press.

Lund, H.L. 1994. "Property Rights Legislation in the States: A Review." Bozeman, MT: Political Economy Research Center.

Lund, H.L. 1995. "The Property Rights Movement and State Legislation." in Land Rights: The 1990's Property Rights Rebellion. B. Yandle, ed. Lanham, MD: Rowman \& Littlefield

National Audobon. 1993-1996. State Takings Legislation: A Resource Book for Activists. Washington: National Audobon Society.

O'Leary, R. 1993. "The Progressive Ratcheting of Environmental Laws: Impact on Public Management." Policy Studies Review 12, 3-4: 118-135.

Paul, Ellen F. 1987. Property Rights and Eminent Domain. New Brunswick: Transaction Books.

Portney, Kent E. 1992. Controversial Issues in Environmental Policy: Science v's. Economics v's. Politics. Newbury Park: Sage Publications.

Robison. Wade L. 1994. Decisions in Doubt: The Environment and Public Policy. Hanover, NH: University Press of New England.

Rose, Carol M. 1994. Property and Persuasion: Essays on the History, Theory, and Rhetoric of Ownership. Boulder, CO: Westview Press. 
Rowley, Charles K. ed. 1993. Property Rights and the Limits of Democracy. Brookfield, Vermont: E. Elger.

Siegan, Bernard H. ed. 1977. Planning without Prices: the Taking Clause as it Relates to Land Use Regulation without Compensation. Lexington, MA: Lexington Books.

Stuart, Elaine. 1994. "Posted: Keep Out!” State Government New's 37: 25-7.

Switzer, Jacquline Vaughn. 1996. "Women and Wise Use: The Other Side of Environmental Activism." Paper delivered at the 1996 Annual Meeting of the Western Political Science Association, San Francisco. March 14-16.

Tokar, Brian. 1995. "The 'Wise Use' Backlash" The Ecologist 28, 4: 150-156.

Torres, Gerald. 1996. "Taking and Giving: Police Power, Public Value. and Private Right" Environmental Law 26, 1: 1-17.

United States House Committee on Resources. 1995. "Private property rights: hearing, part 1, May 17 \& June 3, $1995 . . . "$

Vig, Norman J. and Michael E. Kraft. 1994. Environmental Policy in the 1990's, Second Edition. Washington: Congressional Quarterly, Inc.

Wise, Charles R. and Kirk Emerson. 1994. "Regulatory Takings: The Emerging Doctrine and Its Implications for Public Administration" Administration and Society 26, 3: 305-336.

Yandle, Bruce. 1989. The Political Limits of Environmental Regulation. New York: Quorum Books. 